\title{
Diversidade taxonômica de Apocynaceae na ilha do Marajó, PA, Brasil
} Taxonomic diversity of Apocynaceae at the Marajó Island, PA, Brazil

\author{
Simone Silva Viana ${ }^{2,5}$, João Ubiratan Moreira dos Santos ${ }^{3} \&$ André Olmos Simões ${ }^{4}$
}

\begin{abstract}
Resumo
Este trabalho apresenta um tratamento taxonômico das espécies de Apocynaceae ocorrentes na ilha do Marajó, PA. Foram analisados materiais dos herbários IAN, INPA, MG, R, RB, SP, SPF e UEC e realizadas três viagens de campo para coleta nos anos de 2011 e 2012. A família está representada por 33 espécies distribuídas em 21 gêneros, sendo seis gêneros com sete espécies pertencentes à subfamília Apocynoideae, cinco gêneros e 12 espécies à subfamília Asclepiadoideae e nove gêneros e 14 espécies à subfamília Rauvolfioideae. Prestonia annularis é registrada pela primeira vez para o Estado do Pará, enquanto Spongiosperma grandiflorum e Macoubea guianensis são novos registros para a ilha do Marajó. Forsteronia paludosa, até a realização deste trabalho, era conhecida apenas pela coleção tipo. São apresentadas chaves de identificação, descrições morfológicas, informações sobre fenologia e habitat, distribuição geográfica e comentários taxonômicos e ilustrações das espécies; dentre estas, Forsteronia paludosa e Macoubea guianensis são ilustradas pela primeira vez.

Palavras-chave: Apocynoideae, Asclepiadoideae, Rauvolfioideae, taxonomia.
\end{abstract}

\begin{abstract}
This work presents a taxonomic treatment of species of Apocynaceae occurring in Marajó Island. We analyzed materials from the herbaria IAN, INPA, MG, R, RB, SP, SPF e UEC, as well as specimens collected in three field trips made in July 2011, November 2011 and February 2012. The family is represented in the studied area by 33 species belonging to 21 genera, as follows: six genera with seven species belonging to subfamily Apocynoideae, five genera and 12 species belonging to subfamily Asclepiadoideae, and nine genera with 14 species from subfamily Rauvolfioideae. Prestonia annularis is registered for the state of Pará for the first time, while Spongiosperma grandiflorum and Macoubea guianensis are new records for the Marajó Island. Up to this work, Forsteronia paludosa was known only by the type collection. We provide identification keys, morphological descriptions, phenology and habitat information, geographical distribution, taxonomic comments and illustrations of the species. Forsteronia paludosa and Macoubea guianensis are here illustrated for the first time.
\end{abstract}

Key words: Apocynoideae, Asclepiadoideae, Rauvolfioideae, taxonomy.

\section{Introdução}

Apocynaceae Adans. é uma das maiores e mais representativas famílias de angiospermas e pertence à ordem Gentianales, com cerca de 255 gêneros e 3700 espécies com distribuição predominantemente pantropical (Morales 2005; Endress et al. 2014). No Brasil, são registrados 77 gêneros e 753 espécies (BFG 2015). Atualmente cinco subfamílias são reconhecidas em Apocynaceae: Rauvolfioideae Kostel., Apocynoideae Burnett., Periplocoideae R.
Br. ex Endl., Secamonoideae Endl. e Asclepiadoideae R. Br. ex Burnett, (Endress \& Bruyns 2000). Destas, Rauvolfioideae, Apocynoideae e Asclepiadoideae ocorrem no Brasil, sendo Periplocoideae e Secamonoideae representada por algumas poucas espécies cultivadas.

A família ocorre em todos os domínios fitogeográficos brasileiros (BFG 2015). No Brasil, a família tem sido amplamente estudada principalmente em tratamentos taxonômicos para floras locais e, mais

\footnotetext{
${ }^{1}$ Parte integrante da dissertação de Mestrado do primeiro autor.

${ }^{2}$ Museu Paraense Emílio Goeldi - MCT, Campus de Pesquisa, Coord. Botânica, Av. Perimetral 1901, 66017-970, Belém, PA, Brasil. simonesviana@hotmail.com

${ }^{3}$ Universidade Federal Rural da Amazônia, Inst. Ciências Agrárias - UFRA, Av. Pres. Tancredo Neves 2501, 66077-530, Belém, PA, Brasil. bira@museu-goeldi.br

${ }^{4}$ Universidade Estadual de Campinas, Depto. Biologia Vegetal, Inst. Biologia - Unicamp, R. Monteiro Lobato 255, 13083-862, Campinas, SP, Brasil. aosimoes@unicamp.br

${ }^{5}$ Autor para correspondência: simonesviana@hotmail.com
} 
recentemente, em estudos filogenéticos (ex., Rapini et al. 2006; Simões et al. 2006; Farinaccio 2007). No entanto, esses estudos taxonômicos se concentram nas regiões Sul e Sudeste do Brasil (ex., Bragatto \& Kinoshita 1994; Koch \& Kinoshita 1999; Simões \& Kinoshita 2002; Farinaccio \& Mello-Silva 2004; Fontella-Pereira et al. 2005; Kinoshita \& Simões 2005; Kinoshita et al. 2005; Monguilhott \& MelloSilva 2008; Rapini 2010; Matozinhos \& Konno 2011; Morokawa et al. 2013).

O conhecimento taxonômico de Apocynaceae para a região Norte do Brasil, principalmente para a região Amazônica, ainda é bastante incompleto. Existem apenas dois estudos florísticos realizados para a família, um deles na Reserva Ducke, na região metropolitana de Manaus, AM (Vicentini \& Oliveira 1999) - que ainda hoje é a principal referência para taxonomistas que estudam plantas nesta área - e outro para a bacia dos rios Afuá e Anajás, na ilha do Marajó, PA (Amaral et al. 2007).

Este trabalho teve por objetivo estudar a diversidade taxonômica das Apocynaceae na ilha do Marajó, apresentando descrições, chaves analíticas, ilustrações para o reconhecimento e identificação de suas espécies e contribuir a lista da Flora do Brasil.

\section{Material e Métodos}

\section{Área de estudo}

A ilha do Marajó pertence ao Arquipélago do Marajó, um complexo flúvio-marinho composto por dezenas de ilhas localizadas no litoral amazônico do Norte do estado do Pará (Amaral et al. 2007). O arquipélago possui abundantes recursos hídricos e uma alta diversidade biológica quando comparado a outras regiões do País, é considerado uma das regiões mais biodiversas do país (Brasil 2007). Com 49.606 $\mathrm{km}^{2}$ de extensão, a ilha do Marajó está localizada no extremo Norte do estado do Pará, nas coordenadas $48^{\circ}-51^{\circ} \mathrm{W}$ e $0^{\circ}-2^{\circ} \mathrm{S}$ (Montag et al. 2009).

A ilha configura-se em duas regiões distintas. A Leste predominam campos alagados e savanas, com abundância de gramíneas e vegetação rasteira entre as plantas lenhosas, geralmente distantes dos rios e susceptível ao fogo. A Oeste localiza-se a região dos furos ou florestas, com diversos canais, rios, pequenas ilhas, trechos de terra firme, várzea e igapó, área coberta por vegetação mais densa (Pires 1973; Cruz 1987).

Foram realizadas três viagens de campo à ilha do Marajó, nos municípios de Cachoeira do Ararí, Muaná, Salvaterra e Soure nos anos de 2011 e 2012. As identificações das espécies foram realizadas com base na literatura especializada por comparação com material herborizado identificado por especialistas e coleções-tipo e/ou fotografias das mesmas. As chaves analíticas, descrições e comentários das espécies foram elaborados a partir das análises dos caracteres vegetativos e reprodutivos dos espécimes coletados e de coleções depositadas nos herbários IAN, INPA, MG, R, RB, SP, SPF, UEC. As siglas dos herbários seguem Thiers (continuamente atualizado). As descrições morfológicas seguem Lawrence et al. (1968), Radford et al. (1974), Harris \& Harris (2001), Ribeiro et al. (1999) e Gonçalves \& Lorenzi (2011) e estão padronizadas para cada subfamília de Apocynaceae, de acordo com as peculiaridades morfológicas de cada grupo.

Para os gêneros são apresentados comentários relativos à sua diversidade, distribuição e características diagnósticas. Gêneros com apenas uma espécie ocorrentes na área estudada não foram descritos. Para as espécies são apresentados comentários relativos aos nomes populares e usos locais (quando existentes), distribuição geográfica, ambientes preferenciais e dados de floração e frutificação, além de comentários taxonômicos. As descrições de família, subfamílias e gêneros são baseadas nas espécies encontradas na área de estudo.

\section{Resultados e Discussão}

$\mathrm{Na}$ área de estudo, foram encontrados 22 gêneros e 33 espécies de Apocynaceae. Destes, seis gêneros e 12 espécies pertencem à Apocynoideae, seis gêneros e sete espécies à Asclepiadoideae e 10 gêneros e 14 espécies à Rauvolfioideae. $\mathrm{O}$ gênero mais diverso foi Odontadenia Benth., com cinco espécies. Forsteronia paludosa Woodson, Prestonia annularis (L.F.) G.Don. e Spongiosperma grandiflorum (Huber) Zarucchi são registradas pela primeira vez na área de estudo.

\section{Chave de identificação para gêneros de Apocynaceae na ilha do Marajó}

1. Corola com pré-floração sinistrorsa; estames não adnatos ao gineceu, não formando ginostégio, anteras com as tecas dispostas ao longo de toda a sua extensão e com dorso não lignificado; sementes nuas, aladas ou ariladas

2. Folhas alternas; ovário semi-ínfero Himatanthus 
2'. Folhas opostas ou verticiladas; ovário súpero.

3. Plantas volúveis ou subarbustos, e neste caso com ramos laterais se originando rente ao solo

4. Ramos eretos ou volúveis; folhas verticiladas, raro opostas; corola infundibuliforme; ovário não lignificado, glabro; fruto tipo cápsula, sementes aladas Allamanda

4'. Ramos sempre volúveis; folhas opostas; corola hipocrateriforme; ovário lignificado, piloso; fruto tipo baga; sementes não aladas.

3'. Árvores ou arbustos, com ramos laterais nunca se originando rente ao solo.

5. Folhas em pares geralmente desiguais; sementes ariladas Tabernaemontana

5'. Folhas em pares iguais; sementes não ariladas

6. Folhas com nervuras secundárias paralelas entre si.

Hancornia

6'. Folhas com nervuras secundárias não paralelas entre si 7

7. Nervação craspedódroma; fruto com mesocarpo lenhoso. Macoubea

7'. Nervação broquidódroma; fruto sem mesocarpo lenhoso. ... 8

8. Corola com lobos 3-4 cm compr.; semente com superfície esponjosa... Spongiosperma

8'. Corola com lobos menores que $3 \mathrm{~cm}$ compr.; semente não esponjosa....

9. Lacínias do cálice sem coléteres; cabeça do estilete sem anel basal

10. Inflorescência terminal; ovário pubescente; cabeça do estilete globosa Parahancornia

10’. Inflorescência axilar; ovário glabro; cabeça do estilete cilíndrica Lacmellea

9’. Lacínias do cálice com coléteres; cabeça do estilete com anel basal Ambelania

1'. Corola com pré-floração dextrorsa ou valvar; estames total ou parcialmente adnatos ao gineceu, formando um ginostégio, anteras com as tecas não dispostas ao longo de toda a sua extensão e com dorso lignificado; sementes comosas, raro nuas

11. Árvores, arbustos ou ervas

12. Folhas com domácias na face abaxial; corona ausente; estames parcialmente adnatos à cabeça do estilete

13. Corola rotácea; ovário densamente piloso; inflorescência tirsiforme; sementes elípticocompressas, comosas. Forsteronia

13'. Corola hipocrateriforme; ovário glabro; inflorescência umbeliforme; sementes cilíndricas, glabras Malouetia

12'. Folhas sem domácias na face abaxial; corona presente; estames totalmente adnatos à cabeça do estilete

14. Ginostégio séssil; corona com segmentos sigmoides; frutos globosos, inflados

Calotropis

14'. Ginostégio estipitado; corona com segmentos corniculados; frutos fusiformes, não inflados Asclepias

11'. Plantas volúveis .15

15. Estames parcialmente adnatos à cabeça do estilete; disco nectarífero presente 16

16. Látex incolor; corola com anel carnoso ao redor da fauce; estames parcialmente exsertos Prestonia

16'. Látex branco; corola sem anel carnoso ao redor da fauce; estames inseridos no tubo da corola.

17. Lacínias do cálice sem coléteres; cabeça do estilete com anel basal

Rhabdadenia

17’. Lácínias do cálice com coléteres; cabeça do estilete sem anel basal 18 
18. Ramos com coléteres na região nodal; folhas adaxialmente providas de coléteres ao longo da nervura central ou restritos à base da lâmina; cabeça do estilete umbraculiforme........ Mandevilla

18'. Ramos sem coléteres na região nodal; folhas sem coléteres; cabeça do estilete fusiforme.

Odontadenia

15'. Estames totalmente adnatos à cabeça do estilete; disco nectarífero ausente ...................................... 19

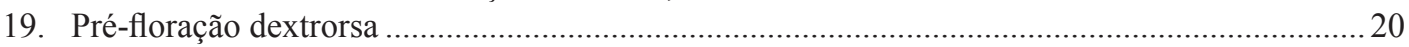

20. Corona com segmentos naviculares; ginostégio séssil; polínia ovoide ............. Blepharodon

20'. Corona com segmentos esféricos, inflados; ginostégio estipitado; polínia oblonga.......

Funastrum

19'. Prefloração valvar

21

21. Ramos com tricomas dispostos em faixa longitudinal; flores com lobos da corola menores que $2 \mathrm{~mm}$ compr.; polínias pendentes..... Tassadia

21'. Ramos glabros, quando glabrescentes com tricomas distribuídos uniformemente; flores com lobos da corola maiores que $3 \mathrm{~mm}$ compr.; polínias horizontais Matelea

\section{Apocynaceae Adans.}

Árvores, arbustos, subarbustos, volúveis ou ervas, latescentes. Folhas opostas, alternas ou verticiladas, com ou sem coléteres na face adaxial. Cálice com coléteres dispostos na base da face adaxial, raro ausentes. Corola actinomorfa, préfloração sinistrorsa, dextrorsa ou valvar. Anteras com as tecas dispostas ao longo de toda a sua extensão ou restritas à sua metade ou terço superior, dorso lignificado ou não, adnatas ou não ao gineceu formando ginostégio, pólen livre ou agrupado em polínias. Gineceu apocárpico a sincárpico, com ápice diferenciado em uma cabeça do estilete; ovário súpero ou semi-ínfero.

Asclepiadoideae R. Br. ex Burnett.

Ervas, arbustos ou plantas volúveis, latescentes. Folhas opostas, com coléteres. Corola com pré-floração dextrorsa ou valvar. Corona presente. Anteras com as tecas não dispostas ao longo de toda a sua extensão e com dorso lignificado, totalmente adnatas ao gineceu formando um ginostégio, pólen agrupado em polínias. Gineceu apocárpico, ovário súpero, placentação marginal. Fruto do tipo folículo; sementes comosas.

\section{Asclepias L., Sp. Pl. 1: 214-214. 1753}

Ervas, látex branco. Folhas pecioladas ou sésseis, com nervação broquidódroma. Inflorescência umbeliforme, terminal ou subaxilar; brácteas persistentes. Cálice com lacínias iguais, coléteres alternos na base. Corola rotácea, préfloração valvar. Corona simples, segmentos livres entre si, corniculados. Ginostégio estipitado. Folículos fusiformes a elipsóides. Sementes verrucosas.

O gênero possui cerca de 490 espécies, das quais seis são encontadas no Brasil, em todas as regiões. Ocorrem de forma espontânea em campos rupestres, cerrados e em áreas degradadas (Kock et al. 2014; Matozinhos \& Konno 2011).

\section{Chave de identificação para as espécies de Asclepias}

1. Folhas pecioladas; lâmina com nervuras secundárias em 9-12 pares; corola vermelha e corona alaranjada 1. Asclepias curassavica

1'. Folhas sésseis; lâmina com nervuras secundárias em 20-25 pares; corola e corona brancas 2. Asclepias mellodora

1. Asclepias curassavica L., Sp. Pl. 1:215. 1753.

Fig. 1a-b

Subarbusto ou erva, 0,7-1 $\mathrm{m}$ alt. Folhas com pecíolo 0,6-1,2 cm compr., lâmina, 7-9,5 $\times 2,7-1,8 \mathrm{~cm}$, membranácea a cartácea, elíptica, estreito-elíptica a lanceolada, ápice agudo a acuminado, base atenuada, face adaxial pubescente, face abaxial esparsamente glabrescente, nervuras secundárias em 9-12 pares. Inflorescência terminal, 7-10 flora; pedúnculo 3-5,5 cm compr.; brácteas 2-3 mm compr., lanceoladas. Pedicelo 1,3-1,8 cm compr. Cálice com lacínias 3,5-5 mm comp., 

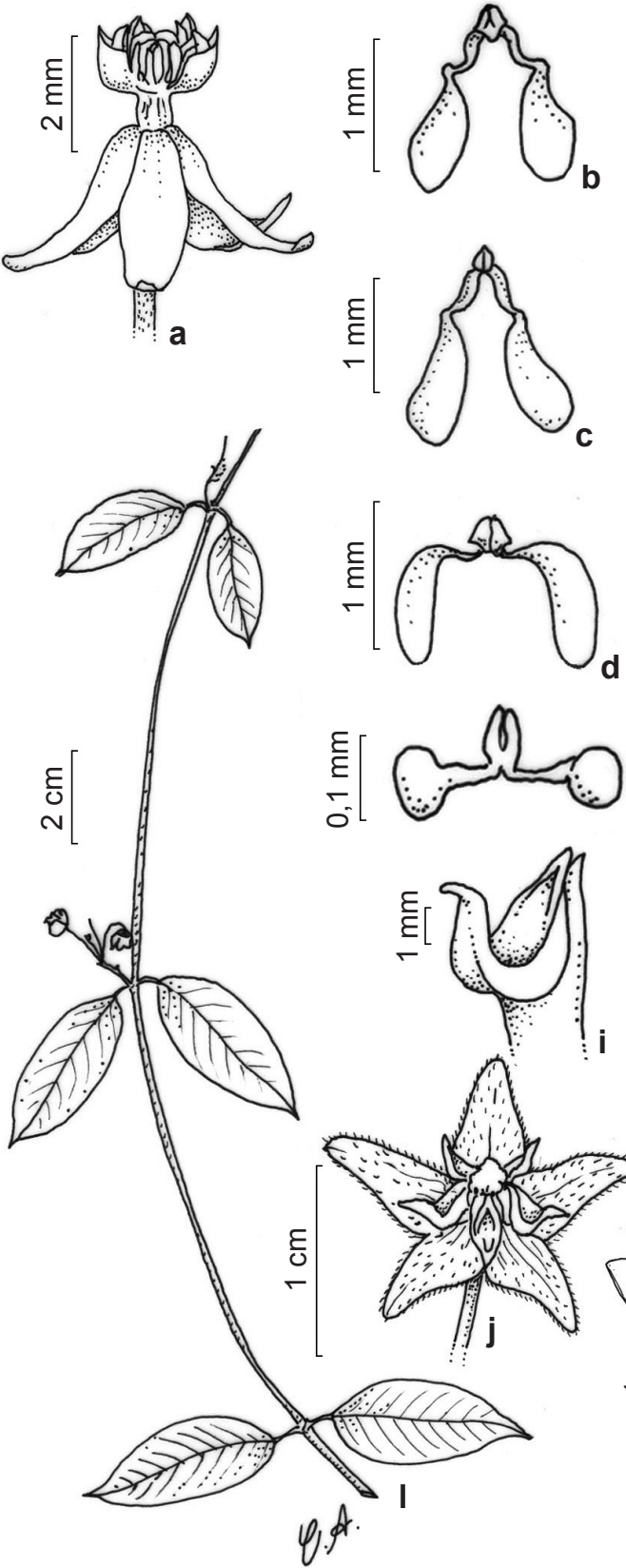
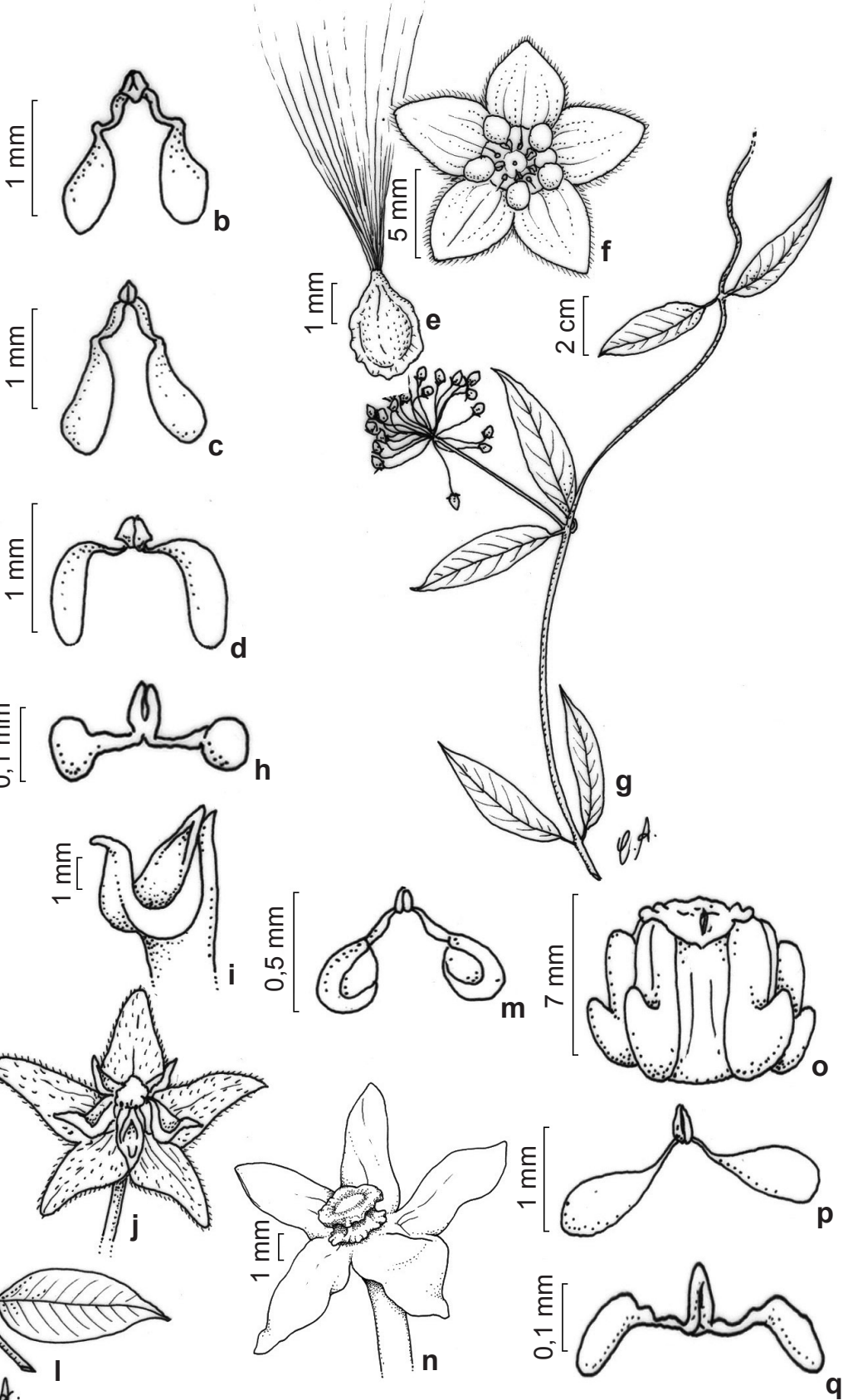

Figura 1 - a-b. Asclepias curassavica L. - a. flor evidenciando o ginostégio; b. polinário. c. A. mellodora A.St.-Hil. polinário. d-g. Funastrum clausum (Jacq.) Schult. - d. polinário; e. semente; f. flor; g. ramo florido. h-1. Blepharodon pictum (Vahl) W.D. Stevens. - h. polinário; i. lobo da corona; j. flor; 1. ramo florido. m-n. Matelea stenopetala Sandwith Bull. - m. polinário; n. flor. o-p. Calotropis procera (Aiton) W.T. Aiton-o. ginostégio; p. polinário. q. Tassadia propiqua Decne. - polinário. (a-b. Viana et al. 27; c. Rocha et al. 1294; d-g. Viana et al.71; h-1. Viana et al. 62; m-n. Sobel et al. 4816; o-p. Viana et al. 79; q. da Costa Neto et al. 197).

Figure 1 - a-b. Asclepias curassavica L. - a. flower showing gynostegium; b. pollinarium. c. A. mellodora A.St.-Hil. - pollinarium. d-g. Funastrum clausum (Jacq.) Schult. - d. pollinarium; e. seed; f. flower; g. flowering branch. h-l. Blepharodon pictum (Vahl) W.D. Stevens. - h. pollinarium; i. corona lobe; j. flower; 1. flowering branch. m-n. Matelea stenopetala Sandwith Bull. - m. pollinarium; n. flower. o-p. Calotropis procera (Aiton) W.T. Aiton - o. gynostegium; p. polinarium. q. Tassadia propiqua Decne. - pollinarium. (a-b. Viana et al. 27; c. Rocha et al. 1294; d-g. Viana et al.71; h-1. Viana et al. 62; m-n. Sobel et al. 4816; o-p. Viana et al. 79; q. the Costa Neto et al. 197). 
lanceoladas. Corola vermelha; tubo ca. de 1 mm compr.; lobos 6-10 × 2-3 mm, oblongos a estreito-elípticos, reflexos. Corona alaranjada, cornículo interno curvo inserido na base da corona, segmentos 2,8-4 mm compr., adnatos à base das anteras. Estames com anteras 2-2,3 $\mathrm{mm}$ compr., retangulares a quadrangulares, membrana ápical triangular; retináculo 0,28-0,4 mm comp., rombóide, caudícula $0,2-0,35 \mathrm{~mm}$ compr., oblíqua, polínias 0,9-1,2 mm compr., claviformes, pendentes. Ginostégio 4,8-5,2 mm compr.; cabeça do estilete 1,7-1,9 mm compr., subcilíndrica. Folículos $4 \times 2,5 \mathrm{~cm}$ compr., fusiformes. Sementes não observadas.

Material selecionado: Chaves, arredores do aeroporto, 21.VI.1978, fl., N.A. Rosa 2447 (IAN, MG); Muaná, rio Atuá, 1.XI.2011, fl. e fr., S.S. Viana et al. 27 (MG).

Espécie de ampla distribuição geográfica, presente em todas as regiões brasileiras (BFG 2015). Floresce em todo o ano e frutifica de agosto a novembro (Rapini et al, 2001; Kinoshita et al. 2005). Na região de estudo, foi coletada com flores em junho e novembro e com frutos em novembro. A espécie foi encontrada em ambiente perturbado por ação antrópica, beira de rio e campo aberto temporariamente alagado. Asclepias curassavica caracteriza-se por apresentar corola vermelha e lobos da corona alaranjados. Popularmente conhecida como falsa-erva-de-rato ou oficialde-sala, possui látex altamente tóxico (FontellaPereira et al. 2005).

2. Asclepias mellodora A.St.-Hil., Hist. P1. Remarq. Bresil. 227. $1824 . \quad$ Fig. 1c

Erva, 0,3-0,4 $\mathrm{m}$ alt. Folhas sésseis, lâmina 10-15 × 0,5-1,5 cm, membranácea, linear a estreito-lanceolada, ápice agudo, base atenuada, face adaxial glabrescente, face abaxial glabra a glabrescente, nervuras secundárias em 20-25 pares. Inflorescência terminal, 9-20 flora; pedúnculo 2,5-3,5 cm compr., brácteas 2-3 mm compr., lanceoladas. Pedicelo 1,3-2 cm compr. Cálice com lacínias 2-3 mm compr., lanceoladas a elípticas. Corola branca; tubo ca. de $1 \mathrm{~mm}$ compr; lobos 7-9 × 3-4 mm, elípticos, reflexos. Corona branca, cornículo interno curvo, inseridos na base da corona, segmentos 4-7 mm compr., adnatos à base das anteras. Estames com anteras 2,5-3 mm compr., retangulares, membrana apical triangular; retináculo $0,25-0,44 \mathrm{~mm}$ compr., ovóide, caudícula 0,2-0,3 mm compr., oblíquo-descendente, polínias 1-1,2 mm compr., claviformes, pendentes. Ginostégio 4-5 mm compr.; cabeça do estilete 1,5-1,8 mm compr., subcilíndrica. Frutos e sementes não observados. Material selecionado: Salvaterra, Joanes, 19.V.2010, fl., A.E.S. Rocha et al. 1294 (MG); Condeixas, 10.I.1982, fl., C.S. Rosário et al. 118 (IAN).

Espécie de ampla distribuição geográfica, mas com registro apenas para o estado do Pará na região Norte (BFG 2015). Floresce e frutifica de outubro a janeiro e abril. Na região de estudo, foi coletada com flores em novembro janeiro e maio, em savana. Asclepias mellodora caracteriza-se por apresentar flores alvas, sendo que as folhas apresentam ampla variação quanto à forma e dimensões. A espécie é popularmente conhecida por lanche-de-víbora (Fontella-Pereira et al 2005; Rapini 2010).

3. Blepharodon pictum (Vahl) W.D. Stevens, Novon 10(3): 242. $2000 . \quad$ Fig. 1h-1

Plantas volúveis. Folhas com pecíolo 0,5-0,9 cm compr., lâmina 4,8-8,5 × 1,5-3 cm, cartácea, elíptica, estreito-elíptica a lanceolada, ápice apiculado a agudo, base cuneada, face adaxial glabra a glabrescente, face abaxial glabrescente, nervação broquidódroma, nervuras secundárias em 10-12 pares. Inflorescência corimbiforme, extra-axilar, 3-7 flora; pedúnculo 4-8 mm compr.; brácteas 0,6-1,8 mm compr., estreito-triangulares a ovais. Pedicelo $16-20 \mathrm{~mm}$ compr. Cálice com lacínias 1,2-2 mm compr., iguais, ovais, coléteres alternos na base. Corola rotácea, alvo-esverdeada; pré-floração dextrorsa; tubo 1,2-1,8 mm compr.; lobos 6-8 $\times 4 \mathrm{~mm}$, ovais a triangulares, patentes. Corona simples, hialina, do mesmo tamanho do ginostégio, segmentos 4-6 mm compr., naviculares, adnatos ao dorso das anteras e livres no ápice, porção proximal prolongada em lobo acuminado. Estames com anteras 2,5-3 mm compr., retangulares, membrana ápical triangular a oval; retináculo 0,1-0,12 mm compr., oblongo, caudícula 0,06-0,08 mm compr., horizontal, polínias $0,08-0,1 \mathrm{~mm}$ compr., ovoides, pendentes. Ginostégio 3-4 mm compr., séssil; cabeça do estilete $0.8-1,2 \mathrm{~mm}$ compr., obcônica. Frutos e sementes não observados.

Material selecionado: Muaná, 21.II.1970, fl., E. Oliveira 5109 (IAN); Patauateua, 3.IX.2011, fl., S.S. Viana et al. 43 (MG); Salvaterra, Água Boa, 28.II.2012, fl. e fr., S.S. Viana et al. 62 (MG).

Blepharodon Decne. é um gênero com cerca de 30 espécies, das quais 13 ocorrem no Brasil (BFG 2015). O gênero é facilmente reconhecido por sua corona com segmentos naviculares e no geral possuem flores maiores que as das demais 
Asclepiadoideae brasileiras (Farinaccio \& MelloSilva 2004). Blepharodon pictum ocorre em todas as regiões brasileiras (BFG 2015), florescendo e frutificando em praticamente todo o ano (Farinaccio \& Mello-Silva 2004; Fontella-Pereira et al. 2005). Na área de estudo foi coletada em capoeira, com flores em janeiro e setembro. A espécie é muito semelhante à B. bicuspidatum, diferenciando por apresentar flores maiores e polínias ovoides a subglobosas (Farinaccio \& Mello-Silva 2004; Rapini 2010).

4. Calotropis procera (Aiton) W.T. Aiton, Hort. Kew. 2 ed. 2: 78.1811.

Fig. 1o-p

Arbusto, 1,5-2 $\mathrm{m}$ de alt. Folhas sésseis, lâmina 16-21 × 9-14 cm, coriácea a cartácea, obovadas a oblongas, ápice apiculado a acuminado, base cordiforme, face adaxial glabra a pulverulenta, face abaxial glabra a pulverulenta, nervação broquidódroma, nervuras secundárias em 9-11 pares. Inflorescência umbeliforme, axilar, 15-25 flora; pedúnculo 4-5 cm compr., brácteas não observadas. Pedicelo $1,8-2,50 \mathrm{~cm}$ compr. Cálice com lacínias 3,8-4,5 mm compr., iguais, ovais a triangulares, coléteres alternos na base. Corola rotácea, alva, arroxeada no ápice dos lobos; pré-floração dextrorsa; tubo 5-6 mm compr.; lobos 8-13 × 4-7 mm, ovais, levemente inflexos. Corona simples, degradê de branco a vináceo, do mesmo tamanho do ginostégio, segmentos 5-7 mm compr., sigmóides, arredondados no ápice e involutos na base. Estames com anteras 4-5 mm compr., retangulares; retináculo $0,4-0,45 \mathrm{~mm}$ compr., oblongo, caudículas 0,3-0,35 mm compr., sub-horizontais, polínias $1-1,3 \mathrm{~mm}$ compr., claviformes, pendentes. Ginostégio 6-7 $\mathrm{mm}$ compr., séssil; cabeça do estilete 1,8-2 mm compr., estreliforme. Folículos 6-10 × 5-6,5 cm, globosos, inflados. Sementes 6-8 × 4,5-6 mm, oval; coma 4-5 cm compr.

Material selecionado: Soure, 29.II.2012, fl. e fr., S.S. Viana et al. 79 (MG).

Calotropis R. Br. possui três espécies tropicais afro-asiáticas. Destas, apenas $C$. procera ocorre no Brasil de forma subespontânea, preferencialmente em regiões secas e quentes do Norte e Nordeste do país (Fontella-Pereira et al. 2005; Rapini 2010; The Plant List 2013; BFG 2015). Espécie de ampla distribuição geográfica, ausente apenas na região Sul (BFG 2015). Floresce em praticamente todo o ano (Farinaccio \& Mello-Silva 2004; Fontella-Pereira et al. 2005;
Góes \& Pereira 2009). Na região de estudo, foi encontrada em beira de rio nas proximidades do município de Soure, e coletada com flores e frutos em fevereiro. De acordo com Rangel \& Nascimento (2011), é considerada uma espécie ruderal, ocupando regiões com ação antrópica. A espécie é popularmente conhecida por ciumeira, saco-velho ou algodão-de-seda.

5. Funastrum clausum (Jacq.) Schult., Syst. Veg. 6: 114-115. $1820 . \quad$ Fig. 1d-g

Plantas volúveis. Folhas com pecíolo 0,3-1 cm compr, lâmina 2,5-6 × 1-3 cm, membranácea, elíptica, estreito-elíptica, lanceolada a ovada, ápice acuminado, agudo a cuspidado, base cuneada, arredondada a levemente cordada, face adaxial glabra a glabrescente, face abaxial glabrescente, nervação broquidódroma, nervuras secundárias em 8-9 pares. Inflorescência umbeliforme, axilar, 18-32 flora; pedúnculo 4-11 cm compr., brácteas $1 \mathrm{~mm}$ compr., lineares a lanceoladas. Pedicelo 4-8 mm comp. Cálice com lacínias 2-3 mm compr., iguais, ovais, coléteres alternos na base. Corola rotácea, alva; pré-floração dextrorsa; tubo 1,2-2 mm comp.; lobos 5-7 × 3-5 mm, ovais a triangulares, patentes. Corona dupla, branca, segmentos esféricos inflados, do mesmo tamanho que o ginostégio, segmentos 3-5 mm compr., adnatos no dorso das anteras, livres no ápice, unidos na base formando um anel carnoso. Estames com anteras 2-3 mm compr., retangulares a ovais; retináculo $0,2-0,3 \mathrm{~mm}$ compr., triangular a sagitado, caudícula ca. 0,1 mm compr., subséssil, horizontal, polínias 0,8-1 $\mathrm{mm}$ compr., oblongas, pendentes. Ginostégio 2-2,3 mm compr., estipitado; cabeça do estilete 1,5-1,8 mm compr., cônica. Folículos 2,5-3,8 $\times$ 1,3-2,3 cm, elipsóides. Sementes 2-3 × 2-2,5 $\mathrm{mm}$, verrucosas, oval; coma 1,3-1,5 cm compr. Material selecionado: Soure, PA-154, 22.V.2011, fl. e fr., C.S. Costa 511 (MG); PA-154, 29.II.2012, fl. e fr. S.S. Viana 71 (MG).

Funastrum E. Fourn. abrange três espécies com ampla distribuição geográfica no Brasil (BFG 2015), das quais somente F. clausum ocorre na área de estudo. Esta espécie possui ampla distribuição geográfica, estando presente em todas as regiões brasileiras (BFG 2015). Na região de estudo foi observada com flores de janeiro a maio e com frutos em fevereiro e maio, e coletada em terreno sujeito a inundações. Funastrum clausum é facilmente reconhecida pela presença de lobos da corona vesiculares. 
6. Matelea stenopetala Sandwith, Bull. Misc. Informar. Kew 1931: 485. $1931 . \quad$ Fig. 1m-n

Plantas volúveis. Folhas com pecíolo $1-2 \mathrm{~cm}$ compr., lâmina 6,6-9 × 1,5-2,9 cm, membranácea, estreito-elíptica a lanceolada, ápice agudoacuminado, base cuneada a arredondada, face adaxial glabra a glabrescente, face abaxial glabrescente, nervação broquidódroma, nervuras secundárias em 7-9 pares. Inflorescência racemiforme, axilar, 2-5 flora; pedúnculo 0,6-1,5 $\mathrm{cm}$ compr., brácteas $1 \mathrm{~mm}$ compr., ovais a triangulares. Pedicelo 4-8 mm compr. Cálice com lacínias 1-2 mm compr., iguais, ovadas a lanceoladas, coléteres alternos na base. Corola rotácea, branca a esverdeada; pré-floração valvar; tubo 1-1,2 mm compr.; lobos 4-5 × 1-2 mm, lanceolados a oblongos, patentes. Corona simples, alva, segmentos 0,4-0,6 mm compr., lobados a lacerados, adnatos à base do ginostégio. Estames com anteras $0,2-0,4 \mathrm{~mm}$ compr., quadrangulares; retináculo $0,08-0,1 \mathrm{~mm}$ compr., estreito-ovoide, caudículas $0,12-0,15 \mathrm{~mm}$ compr., horizontais, polínias $0,25-0,27 \mathrm{~mm}$ compr., ovoides com bolsa hialina na região mediana interna, horizontais. Ginostégio 1,7-2 mm compr., subestipitado, amarelo; cabeça do estilete, 0,2-0,3, pateliforme, ápice suavemente côncavo. Frutos e sementes não observados.

Material selecionado: Anajás, 27.X.1984, fl., G.L. Sobel et al. 4816 (MG).

O gênero possui aproximadamente 300 espécies, sendo a circunscrição muito controversa por apresentar características em comum com espécies do gênero Gonolobus Michx. No Brasil ocorrem 44 espécies (Rapini 2010; BFG 2015). Matelea stenopetala possui registro apenas para as regiões Norte e Nordeste (BFG 2015). Coletada com flores, apenas em outubro e novembro, em capoeira e borda de mata sujeita a inundações.

\section{Tassadia propinqua Decne., Prodr. 8: 579.} 1844.

Fig. 1q

Planta volúvel; ramos com tricomas dispostos em faixa longitudinal. Folhas com pecíolo $0,2-0,6$ cm compr., lâmina 2-4,5 × 0,7-2,2 cm, cartácea, elíptica a lanceolada, ápice apiculado, base cuneada, face adaxial glabrescente, face abaxial estrigosa, nervação broquidódroma, nervuras secundárias em 6-7 pares. Inflorescência pleiotirsoide, extraaxilar, 3-7 flora; pedúnculo 2-3 $\mathrm{mm}$ compr., brácteas $0,3-0,4 \mathrm{~mm}$ compr., estreito-triangulares a lanceoladas. Pedicelo 2-3 mm compr. Cálice com lacínias $0,4-0,6 \mathrm{~mm}$ compr., iguais, estreito-ovais a lanceoladas, coléteres alternos na base. Corola rotácea, alva; pré-floração valvar; tubo $0,3-0,4$ mm compr.; lobos $1-1,2 \times 0,6-0,8 \mathrm{~mm}$, ovais a triangulares, patentes. Corona simples, alva, menor que o ginostégio, segmentos $0,3-0,4 \mathrm{~mm}$ compr., irregulares, trilobulados. Estames com anteras 0,2-0,3 mm compr., quadrangulares; retináculo 0,09-0,1 mm compr., oblongo, caudículas 0,04 $0,05 \mathrm{~mm}$ compr., horizontais, polínias $0,09-0,1$ $\mathrm{mm}$ compr., oblongas, pendentes. Ginostégio 1-1,2 mm compr., subestipitado, alvo; cabeça do estilete 0,1-0,2 $\mathrm{mm}$ compr., ovoide, ápice bilobado. Folículos 3,5-4 cm compr., fusiformes com parte basal mais alargada. Sementes 7-9 $\times$ 2-4 mm compr., verrucosas; elípticas; coma 10-13 mm compr.

Material selecionado: Anajás, s. loc. 18.I.1998, fl., S.V. da Costa et al. 197 (MG); Joanes, s. loc., 10.II.1977, fl., P.R.P. Bouças 174 (IAN).

O gênero possui 20 espécies, das quais 15 ocorrem no Brasil em todo o território nacional (The Plant List 2013; BFG 2015), e tem como características diagnósticas um par de coléteres lateralmente ao pecíolo e flores diminutas, com menos de $2 \mathrm{~mm}$ (Rapini 2010). Espécie de ampla distribuição geográfica, presente em todas as regiões brasileiras (BFG 2015). Floresce durante todo o ano, tendo sido encontrada com flores em janeiro e fevereiro, em área sujeita a inundações. Tassadia propiqua apresenta folhas claras em material herborizado e lobos da corona trilobulados, sendo o mediano depressamente ovado e os adjacentes denteados. Este conjunto de características, encontradas nos exemplares coletados na área de estudo, é considerado por Rapini (2010) como diagnósticas da espécie.

\section{Apocynoideae Burnett.}

Árvores, arbustos, ervas ou plantas volúveis, látex branco ou incolor. Folhas opostas, coléteres presentes ou não. Corola com pré-floração dextrorsa. Corona ausente. Anteras com as tecas não dispostas ao longo de toda a sua extensão e com dorso lignificado, parcialmente adnatas ao gineceu formando um ginostégio, pólen não agregado em polínias. Gineceu apocárpico, ovário súpero, placentação marginal. Fruto do tipo folículo. Sementes comosas, raro glabras.

8. Forsteronia paludosa Woodson, Ann. Missouri Bot. Gard. 21: 620-621. $1934 . \quad$ Fig. 2a-1 Subarbusto, 0,5-0,8 $\mathrm{m}$ alt., látex branco, ramos glabros. Folhas com pecíolo $0,1-0,3 \mathrm{~cm}$ 


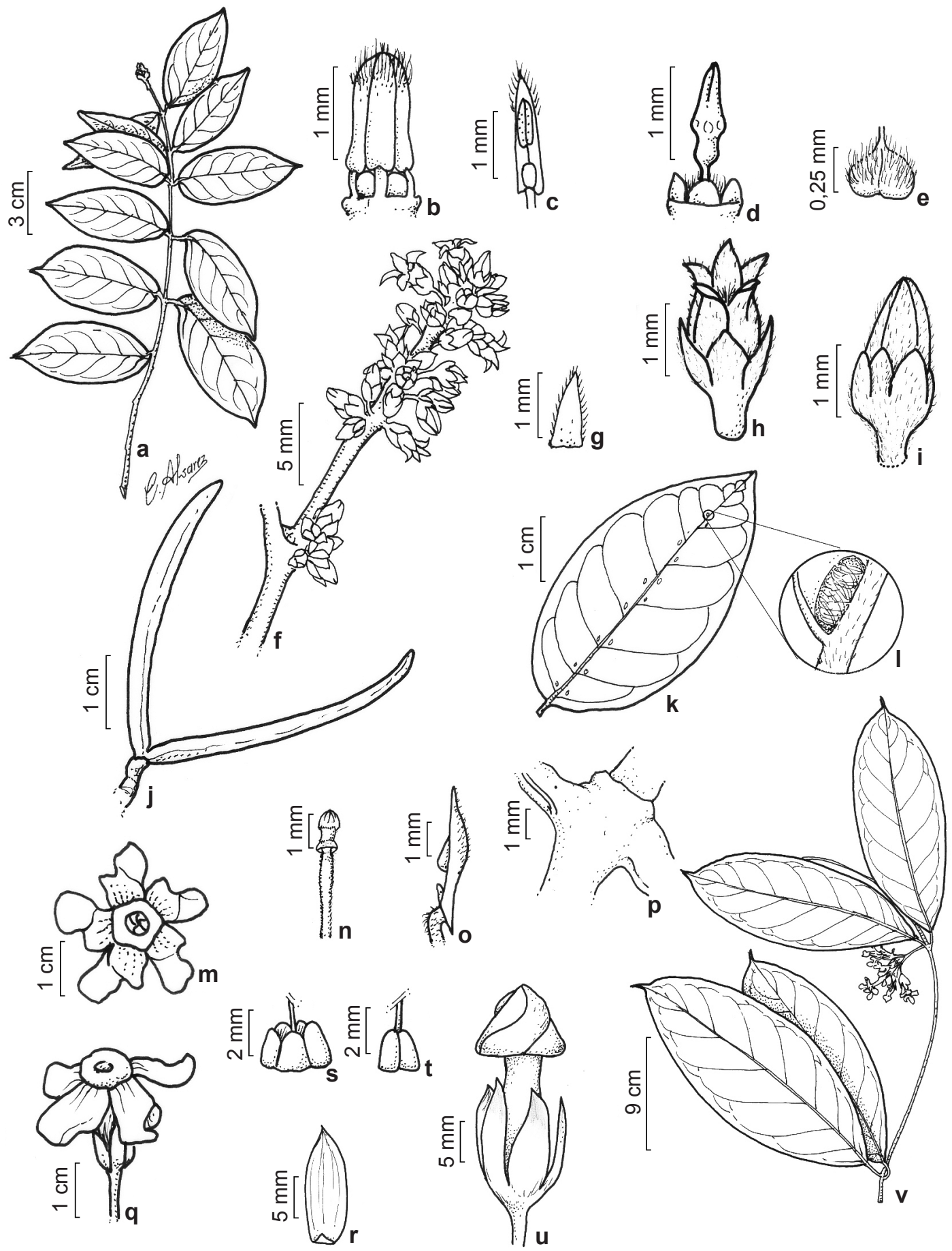

Figura 2 - a-1. Forsteronia paludosa Woodson - a. ramo estéril; b.anteras adnatas à cabeça do estilete; c. antera, face ventral; d. gineceu e disco nectarífero; e. ovário; f. inflorescência; g. lacínia do cálice em face adaxial; h. flor; i. botão; j. fruto; k. folha, face abaxial; 1. domácias. m-v. Prestonia annularis (L. f.) G. Don - m. flor em vista frontal; n. cabeça do estilete; o. antera, vista lateral; p. região nodal; q. flor vista lateral; r. lacínia do cálice em face adaxial; s. disco nectarífero; t. ovário; u. botão flora; v. ramo florido. (a-1. Viana et al. 33; m-v. Viana et al. 54).

Figure 2 - a-1. Forsteronia paludosa Woodson - a. sterile branch; b. anthers adnate to the style head; c. anther in ventral view; d. gynoecium and nectary disk; e. ovary; f. inflorescence; g. adaxial surface of calyx lobe; $h$. flower; i. bud; j. fruit; k. leaf blade, abaxial surface; 1 . domatia. $\mathrm{m}$-v. Prestonia annularis (L. f.) G. Don - m. flower in frontal view; n. style head; o. anther in lateral view; p. nodal region; q. flower in lateral view; r. adaxial surface of calyx lobe; s. nectary disk; t. ovary; u. flower bud; v. flowering branch. (a-1. Viana et al. 33; m-v. Viana et al. 54). 
compr., lâmina 4-5,5 × 1,5-2,5 cm, cartácea, elíptica a oblanceolada, ápice agudo, base arredondada, face adaxial glabra, face abaxial escabra, com pontuações escuras esparsas e domácias pilosas nas axilas das nervuras, nervação broquidódroma, nervuras secundárias em 7-9 pares. Inflorescência tirsiforme, terminal, 22-35 flora; pedúnculo 1-3,3 cm compr.; brácteas 0,5-0,8 mm compr., ovais a estreito-triangulares. Pedicelo 0,8-1 mm compr. Cálice com lacínias 0,9-1,3 mm compr., desiguais, ovais, sem coléteres na base. Corola rotácea, alva; tubo inferior $0,25-0,5 \times 1,3-1,4 \mathrm{~mm}$, cilíndrico, tubo superior $0,8-0,9 \times 1,6-1,8 \mathrm{~mm}$, campanulado; lobos 1,3-1,5 × 1-1,2 mm, ovais, suberetos. Estames parcialmente exsertos, inseridos na base do terço inferior do tubo; anteras 1,5-1,7 mm compr., com dorso densamente piloso no terço superior. Gineceu com ovário 0,25-0,3 mm compr., densamente piloso; disco nectarífero 5 -partido um pouco menor que o ovário; estilete 0,2-0,25 mm compr.; cabeça do estilete 1,1-1,5 mm compr., alargada na região mediana, base sem anel. Folículos 4,3 × 0,4 cm, divergentes, cilíndricos a depressos. Sementes 0,7-1,2 $\times$ 0,5-0,8 mm compr., eliptico-compressas; coma 0,7-1,2 cm compr.

Material selecionado: Muaná, Rio Anabijú, 2.XI.2011, fl., S.S. Viana et al. 33 (MG); São Sebastião da Boa Vista, 17.X.1984, fl., G.L. Sobel et al. 4661 (MG).

Forsteronia G. Mey. é um gênero neotropical com aproximadamente 44 espécies. Destas, 25 ocorrem no Brasil, com predominância na região Amazônica (The Plant List 2013; BFG 2015). As espécies do gênero são facilmente reconhecíveis das demais Apocynoideae pelas flores pequenas com corola alva e rotácea, e pelos estames exsertos (Monguilhott \& Mello-Silva 2008). Forsteronia paludosa possui registro para a região Norte apenas no Estado do Pará (BFG 2015). Até a realização deste trabalho, a espécie era conhecia apenas pelo material tipo. Quando coletados espécimes com as características diagnósticas de $F$. paludosa, estes eram identificados apenas em nível de gênero. Há registro de floração em janeiro, julho, outubro e novembro e frutificação em novembro, sendo que na região de estudo foi coletada com flores em janeiro, outubro e novembro e com fruto imaturo em novembro, em campo aberto. Forsteronia paludosa caracterizase pela inflorescência tirsiforme, ausência de coléteres calicinais (Woodson 1935) e principalmente pelo hábito subarbustivo.
9. Malouetia lata Markgr., Notizbl. Königl. Bot. Gart. Berlin 10: 1037. $1930 . \quad$ Fig. 3j-m Árvores, 4-6 m de alt., látex branco. Folhas com pecíolo 0,2-0,4 cm compr., lâmina 7,5-12,5 × 2,5-6 cm, cartácea, elíptica, ápice acuminado, base obtusa a arredondada, face adaxial glabra a esparsamente glabrescente, face abaxial glabra a esparsamente glabrescente, com domácias nas axilas das nervuras, nervação broquidódroma, nervuras secundárias em 8-10 pares. Inflorescência umbeliforme, axiliar a terminal, 2-4 flora; pedúnculo 2-3 mm compr.; brácteas caducas. Pedicelo 2-4 cm compr. Cálice com lacínias 1,9-2,8 mm compr., iguais, ovais, coléteres alternos na base. Corola hipocrateriforme, branca; tubo inferior 6-7 $\times$ 2-3 mm, cilíndrico, tubo superior $1-2 \times 2,5$ $\mathrm{mm}$, cilíndrico; lobos 14-18 × 5-6 mm, ovadolanceolados, patentes. Estames parcialmente exsertos, inseridos no terço superior do tubo; anteras 3-4 mm compr., com dorso pubescente. Gineceu com ovário 1-1,5 mm compr., glabro com o ápice piloso; disco nectarífero 5-partido, com metade do tamanho do ovário; estilete 1-1,5 cm compr.; cabeça do estilete $0,8-1,2 \mathrm{~mm}$ compr., cilíndrica, anel basal ausente. Folículos $2,11-23 \times 0,4-0,8 \mathrm{~cm}$, falcados, cilíndricos, às vezes unidos no ápice. Sementes $3,5-4 \times 0,4-0,6$ $\mathrm{cm}$, cilíndricas, fendidas longitudinalmente, com as extremidades assimétricas, glabras.

Material selecionado: Afuá, Rio Urucú, 12.IX.1992, fl., M.R. Santos 1976 (MG); Muaná, Rio Cajuúba, 4.XI.2011, fr., S. Viana et al. 57 (MG).

Malouetia A. DC. é um gênero neotropical com 33 espécies; destas, 15 ocorrem no Brasil, com predominância na região Norte (Kinoshita et al. 2005; The Plant List 2013; BFG 2015). Malouetia lata é conhecida apenas para a região Norte (BFG 2015). Na área de estudo foi coletado em beira de rio, com flores em setembro e com frutos em novembro. A espécie caracteriza-se por apresentar semente cilíndrica com fissura longitudinal e extremidades assimétricas e folhas glabras a glabrescentes, embora Woodson (1935) a descreva somente com folhas glabras. A espécie se assemelha com M. tamaquarina Markgr., diferindo por características relacionadas aos verticilos florais, como o tamanho do tubo e dos lobos da corola. O exemplar coletado, embora só apresentasse fruto, pode ser identificado pois seus caracteres vegetativos eram coincidentes com outros espécimes herborizados de M. lata. 


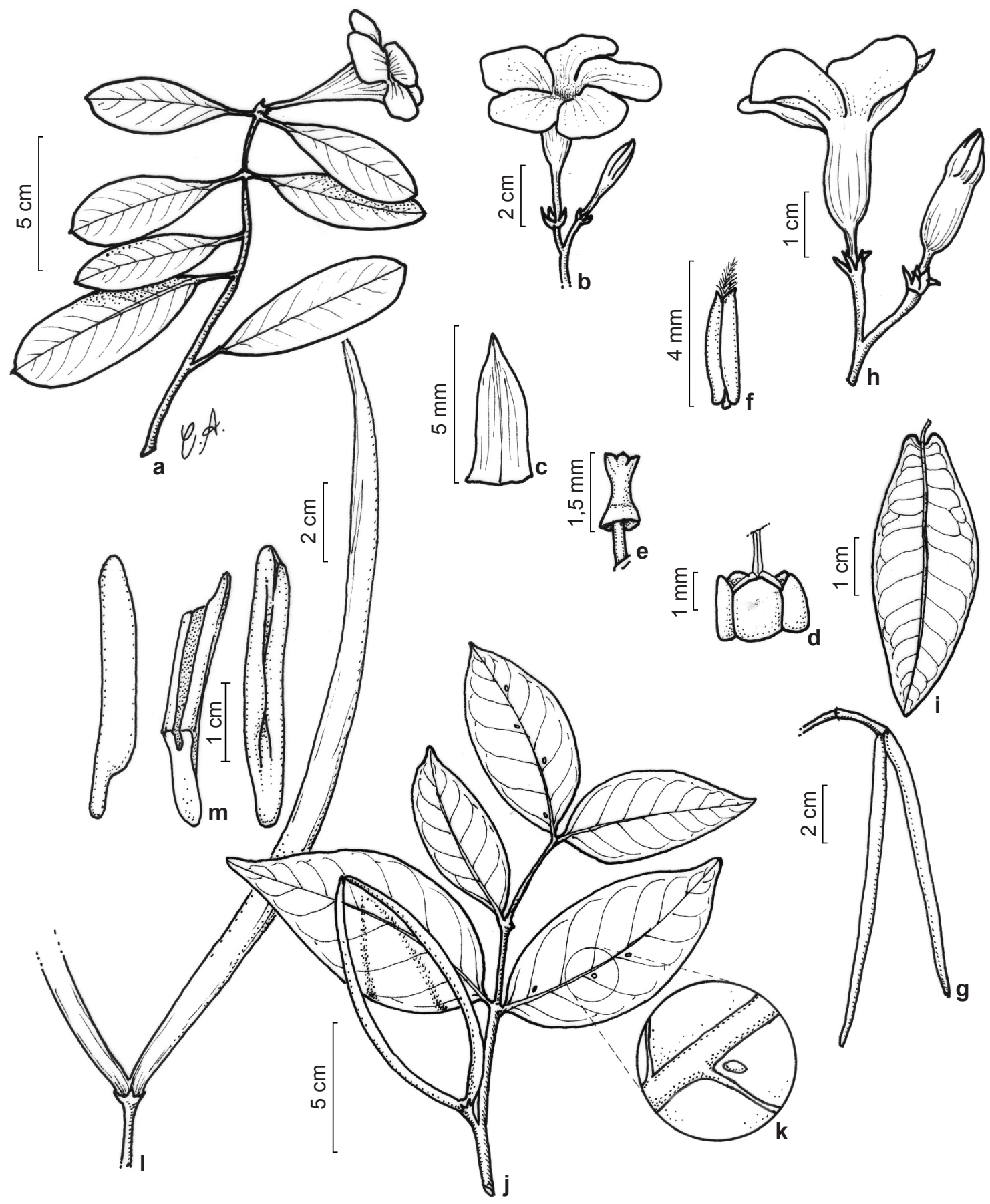

Figura 3 - a-g. Rhabdadenia biflora (Jacq.) Müll.Arg. - a. ramo florido; b. inflorescência; c. lacínia do cálice em face abaxial; d. ovário com disco nectarífero; e. cabeça do estilete; f. antera em vista dorsal; g. fruto. h-i. R. madida (Vell.) Miers. - h. inflorescência; i. lâmina foliar. j-m. Malouetia lata Markgr. - j. ramo com frutos; k. domácias; 1. fruto; m. semente. (a-g. Viana et al.70; h-i. Oliveira 2081; j-m. Viana et al. 57).

Figure 3 - a-g. Rhabdadenia biflora (Jacq.) Müll.Arg. - a. flowering branch; b. inflorescence; c. adaxial surface of calyx lobe; d. ovary with nectary disk; e. style head; f. anther in dorsal view; g. fruit. h-i. R. madida (Vell.) Miers. - h. inflorescence; i. leaf blade. j-m. Malouetia lata Markgr. - j. fruiting branch; k. domatia; 1. fruit; m. seed. (a-g. Viana et al.70; h-i. Oliveira 2081; j-m. Viana et al. 57). 
Mandevilla Lindl., Edwards's Bot. Reg. 26: pl. 7. 1840 .

Liana, látex branco. Folhas opostas, com vários coléteres dispostos ao longo de toda a nervura central, nervação broquidódroma. Inflorescência racemosa. Cálice com coléteres opostos na base. Corola infundibuliforme. Estames inclusos. Gineceu com disco nectarífero 5-lobado, cabeça do estilete umbraculiforme, sem anel basal. Folículos subparalelos ou levemente divergentes, torulosos, às vezes unidos no ápice. Sementes lineares a elípticas, truncadas a rostradas.

Maior gênero neotropical da subfamília Apocynoideae com aproximadamente 170 espécies, das quais 70 ocorrem no Brasil (Morales 2007; BFG 2015). Está presente em todas as regiões do país e suas espécies são facilmente reconhecidas pelas inflorescências racemosas, anteras com base truncada e cabeça do estilete com cinco projeções longitudinais pronunciadas (Simões \& Kinoshita 2002; Monguilhott \& Mello-Silva 2008).

\section{Chave de identificação para espécies de Mandevilla}

1. Brácteas foliáceas, 9-13 mm compr.; cálice com lacínias lanceoladas , 7-10 mm compr.; corola com fauce vermelho-intenso 10. Mandevilla hirsuta

1'. Brácteas escariosas, 0,3-0,5 mm compr.; cálice com lacínias deltoides, 1,3-3,2 mm compr.; corola com fauce alaranjada 11. Mandevilla scabra

10. Mandevilla hirsuta (A. Rich.) K. Schum., Nat. Pflanzenfam. 4(2): 171. 1895.

Liana, ramos hirsutos. Folhas com pecíolo 0,4-2,8 cm compr., lâmina 3,4-12 × 1-6,8 $\mathrm{cm}$, cartácea a membranácea, elíptica, estreitoelíptica, oblonga a obovada, ápice cuspidado, base auriculada, face adaxial pilosa, com coléteres distribuídos ao longo da nervura central, face abaxial pilosa a hirsuta, nervuras secundárias em 10-12 pares. Inflorescência axilar, 8-15 flora; pedúnculo 1-5 $\mathrm{cm}$ compr.; brácteas $9-13 \mathrm{~mm}$ compr., foliáceas, lanceoladas. Pedicelo 1-8 mm compr. Cálice com lacínias 7-10 mm compr., iguais, lanceoladas, coléter solitário e oposto na base. Corola amarela; tubo inferior 27-33 × 1-4 $\mathrm{mm}$, levemente giboso, tubo superior 1-3,9 $\times$ 1,2-3,5 cm, campanulado, fauce vermelho-intenso; lobos 1,5-2 × 1,6-2,5 cm, obovados a oblongos. Estames inseridos no terço mediano do tubo; anteras 4,5-5 mm compr., dorso glabro. Gineceu com ovário 1,9-3 mm compr.; disco nectarífero com metade do comprimento do ovário; estilete 2,5-3,5 cm compr.; cabeça do estilete $2-3 \mathrm{~mm}$ compr. Folículos 13-15 × 0,3-0,5 mm, subparalelos, torulosos, unidos no ápice. Sementes 10-12 × 4-4,5 mm, elipsóide-côncavas; coma 1,2-2,1 cm compr. Material selecionado: Muaná, Rio Patauateua, 3.XI.2011, fl. e fr., S.S. Viana et al. 46 (MG); Salvaterra, Vila Caldeirão 2.III.2012, fl., C.S. Costa et al. 536.

Espécie mais amplamente distribuída do gênero, ocorrendo do México à Argentina (Morales 2007). No Brasil, está presente em todo o território, em formações de mata, cerrado e campo rupestre (BFG 2015; Morales 2005, 2007; Simões \& Kinoshita 2002). Floresce praticamente todo o ano e frutifica de outubro a março (Simões \& Kinoshita 2002; Kinoshita et al. 2005). Na região de estudo foi coletada com flores em janeiro, fevereiro, março, outubro e julho, com frutos em fevereiro, em capoeira, campo aberto e borda de mata. Mandevilla hirsuta é comumente confundida com M. scabra (Hoffmans. ex Roem \& Schult.) K.Schum., mas diferencia-se desta principalmente pelas lacínias do cálice e brácteas de maiores dimensões, e na área de estudo pela coloração da fauce vermelho-intenso. Os indivíduos coletados durante esse trabalho de $M$. hirsuta apresentam pilosidade variando de pilosa à hirsuta no mesmo espécime, mas nunca glabros.

11. Mandevilla scabra (Hoffmans. ex Roem \& Schult.) K.Schum., Nat. Pflanzenfam. 4(2): 171. 1895.

Liana, ramos escabros. Folhas com pecíolo 0,2-1,2 cm compr., lâmina 3,5-9 × 1,3-4,3 cm, cartácea, elíptica, estreito-elíptica, lanceolada, oblanceolada a ovada, ápice agudo a cuspidado, base cordada a auriculada, face adaxial glabra a hirsuto-estrigosa, com coléteres distribuídos ao longo da nervura central, face abaxial hirsuta a pubescente, nervuras secundárias em 8-9 pares. Inflorescência axilar, 10-18 flora; pedúnculo 0,9-2 cm compr.; brácteas $0,3-0,5 \mathrm{~mm}$ compr., escariosas, triangulares. Pedicelo $0,2-0,3 \mathrm{~mm}$ 
compr. Cálice com lacínias 1,3-3,2 mm compr., iguais, deltóides, coléter solitário e oposto na base. Corola amarela, tubo inferior 27-40 × 2,5-3 mm, levemente curvado, tubo superior $1,4-1,8 \times 1,5-2$ $\mathrm{cm}$, campanulado, fauce alaranjada; lobos 1,4-1,8 $\times 1,5-2 \mathrm{~cm}$, oblíquo-ovados, patentes. Estames inseridos no terço mediano do tubo; anteras 4-5 $\mathrm{mm}$ compr., dorso glabro. Gineceu com ovário 20-22 mm compr., disco nectarífero com dois terços do comprimento do ovário; estilete 2,5-2,8 $\mathrm{cm}$; cabeça do estilete 2,2-2,3 mm compr. Frutos e sementes não observados.

Material selecionado: Cachoeira do Ararí, 1.III.2012, fl., C.S. Costa et al. 528 (MG); Salvaterra, Cachoeirinha, 22.VII.2011, fl., S.S. Viana 1 (MG); Muaná, Rio Anabijú, 22.IV.1982, fl., M. Dantas 1082 (IAN).

A espécie possui ampla distribuição em todo o Brasil, em formações de mata, cerrado e campo rupestre (Kinoshita et al. 2005; BFG 2015). Floresce e frutifica em praticamente todo o ano (Watanabe et al, 2009), sendo que na área de estudo foi coletada com flores de março a julho e outubro e frutos imaturos em abril. A espécie foi encontrada em borda de mata, beira de estada, capoeira e campo misto.

Odontadenia Benth., Bot. (Hooker)3: 242. 1841. Plantas volúveis, látex branco, estípulas caducas ou persistentes. Folhas pecioladas ou subsésseis, nervação broquidódroma ou craspedódroma. Inflorescência tirsiforme, dicasial, corimbosa ou escorpióide. Cálice com coléteres alternos na base. Corola infundibuliforme a hipocrateriforme, lobos patentes. Estames inclusos. Gineceu com disco nectarífero lobado a fimbriado; cabeça do estilete fusiforme, sem anel basal. Folículos subparalelos, cilíndricos, subcilíndricos ou achatados. Sementes oblongas a elípticas.

Gênero com 20 espécies, das quais 16 ocorrem em todo o território brasileiro, exceto na região Sul, com maior diversidade na região Amazônica (Morales 1999; BFG 2015).

\section{Chave de identificação para as espécies de Odontadenia}

1. Tubo inferior da corola com constrição; disco nectarífero fimbriado........13. Odontadenia macrantha

1'. Tubo inferior da corola sem constrição; disco nectarífero não fimbriado 2

2. Cálice com lacínias iguais, glabras

3. Corola hipocrateriforme, com nódulos na inserção dos estames; estames inseridos no terço mediano do tubo da corola 12. Odontadenia geminata

3'. Corola infundibuliforme a estreito infundibuliforme, sem nódulos na inserção dos estames; estames inseridos no terço inferior do tubo da corola....

14. Odontadenia nitida

2'. Cálice com lacínias desiguais, pubescentes

4. Inflorescência dicásio axilar a subterminal; ovário totalmente glabro; disco nectarífero laminar maior que o ovário 15. Odontadenia punticulosa

4'. Inflorescência tirsiforme, terminal; ovário com ápice pubescente; disco nectarífero delgado menor que o ovário. 16. Odontadenia verrucosa

12. Odontadenia geminata (Hoffmanns. ex Roem \& Schult.) Müll.Arg. Fl. bras. 6(1): 1191860.

Fig. $4 \mathrm{a}-\mathrm{f}$

Ramos glabros. Folhas com pecíolo 0,4-1 cm de compr., lâmina 4-11 × 1,5-5,5 cm, cartácea, lanceolada, obovada a estreito-elíptica, ápice agudo a obtuso, base aguda, obtusa, raro cordada, faces adaxial e abaxial glabras, nervação broquidódroma, nervuras secundárias em 13-14 pares. Inflorescência dicasial, axilar, 3-8 flora; pedúnculo 1-3,5 cm compr.; brácteas $0,8-1,8 \mathrm{~mm}$ compr., triagulares, glabras. Pedicelo $0,5-1,8 \mathrm{~cm}$ compr. Cálice com lacínias 3-5 mm compr., iguais, triangulares. Corola hipocrateriforme, amarela; tubo inferior
13-20 $\times 2,3-4 \mathrm{~mm}$, cilíndrico, tubo superior 14-23 $\mathrm{mm} \times 23-40 \mathrm{~mm}$, campanulado, fauce alaranjada; lobos $1,8 \times 1,2-1,4 \mathrm{~cm}$, estreito obovados. Estames inseridos no terço mediano do tubo, formando nódulos; anteras 0,8-1,1 cm compr., dorso pubescente a glabro. Gineceu com ovário 1-2 mm compr., glabro; disco nectarífero lobado, com cerca dois terços do comprimento do ovário; estilete 7-1,3 $\mathrm{mm}$; cabeça do estilete $2-3 \mathrm{~mm}$ compr. Folículos $2,7-14 \times 0,6-1 \mathrm{~cm}$, cilíndricos. Sementes 1,5-2 $\times$ 2-4 mm, estreito-elípticas; coma 1,8-2,5 cm compr. Material selecionado: Muaná, Rio Atuá, 2,XI.2011, fl., S.S. Viana et al. 34 (MG); Salvaterra, Deus me ajude, 19.X.2003, fl., L.M.M. Carreira 2462 (MG). 

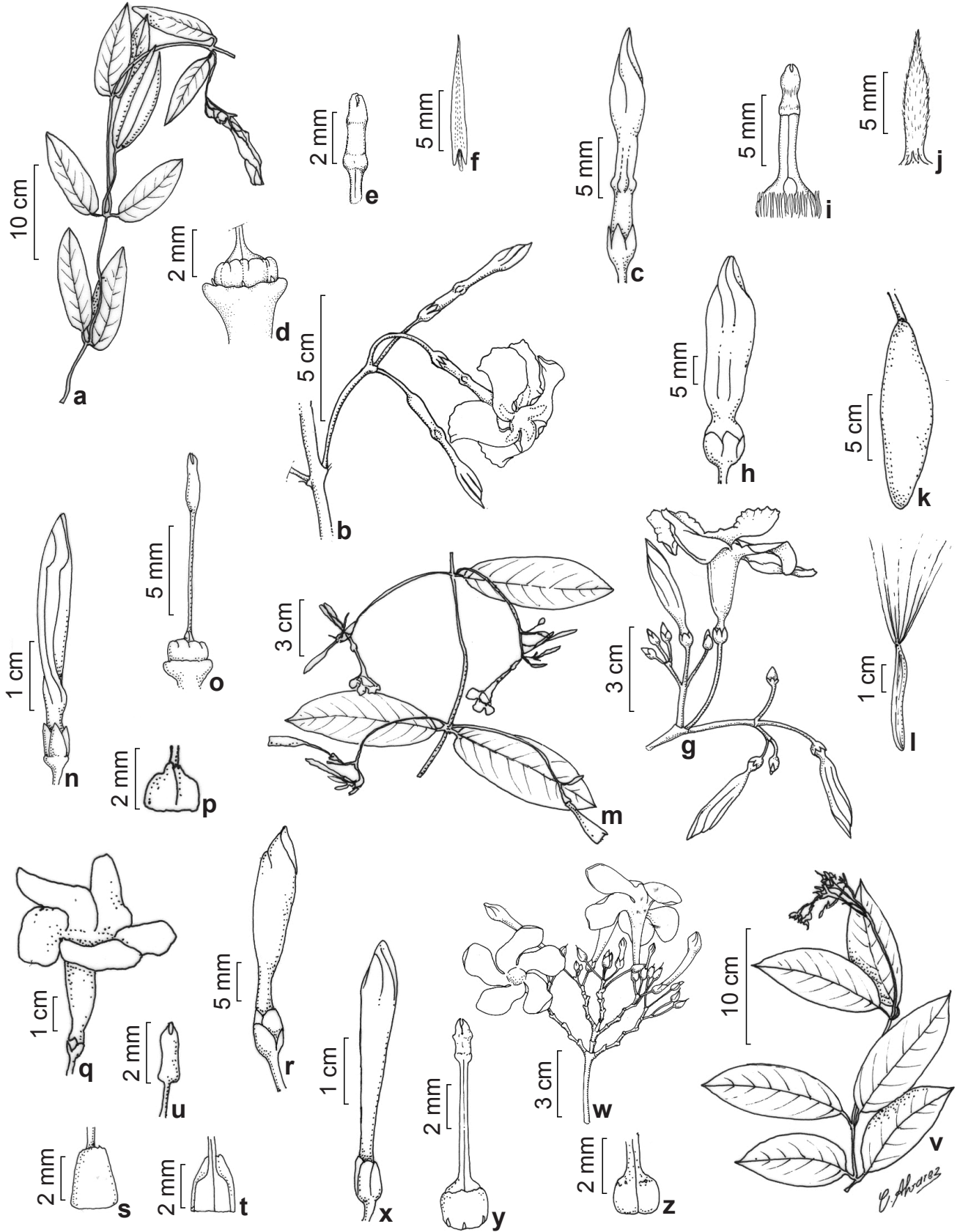

Figura 4 - a-f. Odontadenia geminata (Hoffmanns. ex Roem \& Schult.) Müll.Arg. - a. ramo florido; b. inflorescência; c. botão; d. ovário com disco nectarífero; e. cabeça do estilete; f. antera em vista dorsal. g-1. O. macrantha (Willd. ex Roem. \& Schult.) Markgr. - g. inflorescência; h. botão; i. gineceu; j. antera, vista dorsal; k. fruto; 1. semente. m-p. O. nitida (Vahl) Müll.Arg. M. - m. ramo florido; n. botão; o. gineceu; p. ovário. q-u. O. punticulosa (Rich.) Pulle Enum. - q. flor; r. botão floral; s. disco nectarífero; t. ovário; u. cabeça do estilete. v-z. O. verrucosa (Willd. ex Roem. \& Schult.) K. Schum. ex Markgr- - v. ramo florido; w. inflorescência; x. botão; y. gineceu; z. ovário. (a-f. Viana et al. 34; g-j. Viana et al. 40; k-1. Viana et al. 41; m-p. Costa et al. 512; q-u. Viana 4; v-z. Viana et al. 47).

Figure 4 - a-f. Odontadenia geminata (Hoffmanns. ex Roem \& Schult.) Müll.Arg. - a. flowering branch; b. inflorescence; c. flower bud; d. ovary with nectary disk; e. style head; f. anther in dorsal view. g-1. O. macrantha (Willd. ex Roem. \& Schult.) Markgr. - g. inflorescence; h. flower bud; i. gynoecium; j. anther in dorsal view; k. fruit; l. seed. m-p. O. nitida (Vahl) Müll.Arg. M. - m. flowering branch; n. flower bud; o. gynoecium; p. ovary. q-u. O. punticulosa (Rich.) Pulle Enum. - q. flower; r. flower bud; s. nectary disk; t. ovary; u. style head. v-z. O. verrucosa (Willd. ex Roem. \& Schult.) K. Schum. ex Markgr- - v. flowering branch; w. inflorescence; x. flower bud; y. gynoecium; z. ovary. (a-f. Viana et al. 34; g-j. Viana et al. 40; k-1. Viana et al. 41; m-p. Costa et al.512; q-u. Viana 4; v-z. Viana et al. 47). 
Espécie com registro para as regiões Norte e Centro-Oeste, floresce durante todo o ano, sendo mais comum de janeiro a outubro (BFG 2015; Morales 1999). Na região de estudo foi coletada com flores em outubro, novembro e janeiro e com frutos em novembro, em áreas de campo aberto e borda de mata. Odontadenia geminata é muito semelhante a $O$. nitida (Vahl) Müll.Arg., diferindo desta por apresentar inflorescência dicasial, estames inseridos no terço mediano do tubo da corola, com cinco nódulos salientes visíveis na parte exterior do tubo, folhas discolores e tubo da corola hipocrateriforme.

13. Odontadenia macrantha (Willd. ex Roem. \& Schult.) Markgr., Fl. Suriname 4(1): 461-462. 1937.

Fig. 4g-1

Ramos glabros. Folhas com pecíolo $1-2,4$ cm compr., lâmina 18-24,5 × 7-11,5 cm, cartácea a subcoriácea, elíptica a amplamente elíptica, ápice agudo a cuspidado, base aguda, faces adaxial e abaxial glabras, nervação craspedódroma, nervuras secundárias em 14-16 pares.Inflorescência dicasial, axilar, 8-10 flora; pedúnculo 1,5-8 cm compr.; brácteas 1,1-2 mm compr., triagulares, glabras. Pedicelo 1-2,5 cm compr. Cálice com lacínias 4-8 mm compr., iguais, ovadas a ovadodeprimidas. Corola infundibuliforme, amarela com tons alaranjados; tubo inferior 3-7 × 4-8 mm, cilíndrico, com constrição evidente, tubo superior 15-45 × 10-20 mm, campanulado, fauce alaranjada; lobos 2-3 × 2,3-3,6 cm, obovados a ovados. Estames inseridos no terço inferior do tubo; anteras $10-13 \mathrm{~mm}$ compr., dorso piloso. Gineceu com ovário 3-4 mm compr., glabro; disco nectarífero fimbriado, igual ou maior que o comprimento do ovário; estilete 3-7 mm compr.; cabeça do estilete 3-4 mm compr. Folículos 18-24×4-5 cm, cilíndricos. Sementes 4-5 ×0,3-0,5 cm, estreito-elípticas; coma 2,7-3,2 cm compr. Material selecionado: Muaná, Rio Anabijú, 2.XI.2011, fl. S.S. Viana et al. 40 (MG); São Gerônimo, 2.XI.2011, fr. S.S. Viana et al. $41(\mathrm{MG})$;

Espécie com amplo registro para a região Norte, também alcançando a América Central (Morales 2009a; BFG 2015). Floresce e frutifica durante todo o ano, com pico de floração de dezembro a agosto e de frutificação entre abril e outubro (Morales 1999, 2005). Na região de estudo, foi coletada com flores de setembro a março e com frutos em novembro, em beira de rio. Odontadenia macrantha distingue-se das demais espécies do gênero por apresentar flores grandes e vistosas, com cheiro semelhante à canela, uma constrição na corola no ponto de inserção dos estames, e disco nectarífero fimbriado ou lacerado. A espécie é popularmente conhecida como "pepino-de-índio".

14. Odontadenia nitida (Vahl) Müll.Arg., Fl. bras. 6(1): 118. $1860 . \quad$ Fig. 4m-p

Ramos glabros. Folhas com pecíolo $0,8-1,2$ cm compr.; lâmina 7,5-12 × 2-5,5 cm, cartácea, oblonga, elíptica estreito-elíptica a ovada, ápice agudo a obtuso, base cordada a arredondada, faces adaxial e abaxial glabras, nervação broquidódroma, nervuras secundárias em 14-16 pares. Inflorescência escorpióide, axilar, 4-30 flora; pedúnculo 2,5-7 cm compr.; brácteas 1-1,8 mm compr., triagulares, glabras. Pedicelo 1-2 cm compr. Cálice com lacínias 3-4 mm compr., iguais, ovadas. Corola infundibuliforme, amarela; tubo inferior 6-8 $\times$ $2,3 \mathrm{~mm}$, cilíndrico, tubo superior 20-28 $\times 6-9$ $\mathrm{mm}$, campanulado, fauce amarela; lobos $1,3-1,8$ $\times 0,8-1 \mathrm{~cm}$, obliqualmente obovados, patentes. Estames inseridos no terço inferior do tubo; anteras 0,7-0,9 mm compr., dorso pubescente. Gineceu com ovário 1-1,4 mm compr., glabro; disco nectarífero lobado cerca de metade do comprimento do ovário; estilete 7-9 $\mathrm{mm}$; cabeça do estilete $2-3 \mathrm{~mm}$ compr. Folículos 10-12 × 0,8-1 cm, cilíndricos. Sementes $1,8-2 \times 2-3 \mathrm{~mm}$, rugosas, estreito-elípticas; coma $1,8-2 \mathrm{~cm}$ compr.

Material examinado: Salvaterra, Vila Caldeirão, 28.X.1999, fl., L. Carreira 1947 (MG);Vila Caldeirão, 22.V.2011, fl., C.S. Costa et al.512 (MG).

Espécie com registro para as regiões norte e centro-oeste do Brasil, floresce de março a abril e frutifica de abril a janeiro (BFG 2015; Morales 1999). Na região de estudo foi coletada com flores em maio, outubro e novembro e com frutos em novembro. Odontadenia nitida distingue-se das demais espécies por possuir corola infundibuliforme. De acordo com Morales (1999), está intimamente relacionada com $O$. geminata. Observou-se que em relação a esta, além da distinção da corola, apresenta inflorescência escorpióide e estames inseridos no terço inferior do tubo da corola sem nódulos na parte exterior do tubo.

15. Odontadenia punticulosa (Rich.) Pulle, Enum. Vasc. Pl. Surinam 383. $1906 . \quad$ Fig. 4q-u Ramos pubescentes. Folhas com pecíolo 0,5-1 cm compr., lâmina 5,7-14 × 2,8-7 cm, cartácea, elíptica a amplamente elíptica, ápice agudo a cuspidado, base arredondada a cuneada, faces adaxial e abaxial glabras, nervação broquidódroma, nervuras secundárias em 10-12 pares. Inflorescência dicásio axilar a subterminal, 12-20 flora; pedúnculo 1,3-4 
cm compr.; brácteas 2,6-3 mm compr., triagulares, pubescentes. Pedicelo 1,1-1,8 cm compr. Cálice com lacínias 3-5 mm compr., desiguais, ovadas. Corola infundibuliforme, amarela; tubo inferior $1-1,2 \times 0,5-1 \mathrm{~mm}$, cilíndrico, tubo superior 2,2-3 $\times 0,8-1,3 \mathrm{~mm}$, campanulado, fauce amarela; lobos 1,4-2 × 1-1,8 cm, obovados, patentes. Estames inseridos no terço inferior do tubo; anteras 4-6 mm compr., dorso pubescente. Gineceu com ovário 2-2,8 mm compr., glabro; disco nectarífero laminar, maior que comprimento do ovário; estilete $1-1,2 \mathrm{~cm}$ compr.; cabeça do estilete $2-2,5 \mathrm{~mm}$ compr.. Frutos e sementes não observados.

Material examinado: Salvaterra, Vila União, 22.VII.2011, fl., S.S. Viana 4 (MG).

Espécie com registro para a região Norte e Centro-Oeste do Brasil (BFG 2015). Floresce de março a outubro e frutifica de janeiro a setembro (Morales 1999). Na região de estudo foi coletada com flores em julho, em formações de mata em beira de estrada. Odontadenia punticulosa é muito semelhante a $O$. verrucosa (Willd. ex Roem. \& Schult.) K. Schum., podendo ser reconhecida pela inflorescência dicasial, axilar a subterminal, ovário totalmente glabro e pelo disco nectarífero laminar e maior do que o comprimento do ovário.

16. Odontadenia verrucosa (Willd. ex Roem. \& Schult.) K. Schum. ex Markgr., Fl. Suriname 4(1): 53. 1932.

Fig. $4 \mathrm{v}-\mathrm{z}$

Ramos pubescentes. Folhas com pecíolo 0,5-1,5 cm compr., pubescente, lâmina 7-17 × 2,6-8,5 cm, cartácea, elíptica a obovada, ápice agudo a cuspidado, base obtusa a aguda, face adaxial glabra, face abaxial glabrescente, pilosa nas axilas da nervura primária com a secundária, nervação broquidódroma, nervuras secundárias em 9-11 pares. Inflorescência tirsiforme, terminal, 15-22 flora; pedúnculo 0,8-3 cm compr.; brácteas 1-2 mm compr., triagulares, pubescentes. Pedicelo 0,5-1,5 cm compr. Cálice com lacínias 4-6 mm compr., desiguais, ovadas a estreito ovadas. Corola infundibuliforme, amarela com tons alaranjados; tubo inferior $8-10 \times 1,8-3 \mathrm{~mm}$, cilíndrico, tubo superior $25-35 \times 8-10 \mathrm{~mm}$, campanulado, fauce alaranjada; lobos 1,5-2 × 1,3-1,5 cm, obovados, patentes. Estames inseridos na terço inferior do tubo; anteras 4-5 mm compr., dorso pubescente. Gineceu com ovário 2-2,8 mm compr., pubescente no ápice; disco nectarífero delgado, pouco menor que o comprimento do ovário; estilete 6-8 mm compr.; cabeça do estilete 2-2,6 mm compr. Folículos $10 \times$ $1,4 \mathrm{~cm}$, divaricados, subcilíndricos.
Material selecionado: Muaná, Rio Patuateua, 3.XI.2011, fl., S.S. Viana et al. 47 (MG); São Sebastião da Boa Vista, furo Santo Antônio, XII.1993, fr., R. Lisboa 3096 (MG); Rio Cajuúba, 4.XI.2011, fl., S.S. Viana et al. 24 (MG).

Espécie com registro de coleta apenas para a região Norte, em floresta amazônica (BFG 2015). Segundo Morales (1999), floresce de março a fevereiro e frutifica de dezembro a junho. $\mathrm{Na}$ região de estudo, foi encontrada com flores em outubro e novembro e com frutos em dezembro, em borda de mata.

\section{Prestonia annularis (L.f.) G. Don., Gen. Hist.} 4: 84. 1838.

Fig. 2m-v

Plantas volúveis, látex incolor; ramos glabrescentes. Folhas com pecíolo 0,8-1 cm compr., com apêndice anelar que envolve o caule na inserção do pecíolo, lâmina 19-23 × 6,8-9 $\mathrm{cm}$, cartácea a membranácea, elíptica a oblonga, margem inteira, ápice cuspidado, base cuneada a assimétrica, glabra, nervação broquidódroma, nervuras secundárias em 9 pares. Inflorescência corimbosa, axilar, 12-14 flora; pedúnculo $2 \mathrm{~cm}$ compr.; brácteas $0,8-1,2 \mathrm{~mm}$ compr., deltoides, glabras. Pedicelo 0,8-1,2 cm compr. Cálice com lacínias 1,3-1,5 mm compr., iguais, lanceoladas. Corola hipocrateriforme, amarela, com tons lilases na base do lobo e tubo alvo; tubo inferior $16 \times 4-5 \mathrm{~mm}$, cilíndrico, tubo superior $5 \times 7$ $\mathrm{mm}$, cilíndrico, com anel carnoso ao redor da fauce, fauce branca; lobos $1 \times 0,9 \mathrm{~cm}$, obovados, patentes, sinuosos. Estames parcialmente exsertos com apêndices supraestaminais, inseridos no terço superior do tubo; anteras $5 \mathrm{~mm}$ compr., com dorso pubescente. Gineceu com ovário $2 \mathrm{~mm}$ compr.; disco nectarífero 5-partido, maior que o ovário; estilete 1,3 cm compr.; cabeça do estilete $1,2 \mathrm{~mm}$ compr., cilindrica, com anel membranoso na base. Frutos e sementes não observados.

Material selecionado: Muaná, Furo Pitauã, 4.XI.2011, fl., S.S. Viana et al. 54 (MG).

Prestonia R. Br. possui cerca de 60 espécies nos neotrópicos, das quais 23 ocorrem no Brasil (Kinoshita et al. 2005; BFG 2015). Prestonia annularis é uma espécie pouco coletada e de distribuição geográfica restrita à região Norte (BFG 2015). Até o presente trabalho, era conhecida apenas para o Estado do Amazonas em território brasileiro, sendo este o primeiro registro da espécie para o estado do Pará. Floresce de setembro a novembro, sendo que na área de estudo foi coletada com flores em novembro. Prestonia annularis é distinta das demais espécies do gênero pela 
corola de tubo branco e lobos com a base e centro arroxeados tendendo ao marrom e bordas amarelas, e pelo cálice branco na base e esverdeado no ápice.

Rhabdadenia Müll. Arg., Fl. bras. 6 (1):173. 1860. Plantas volúveis ou ervas, látex branco ou incolor. Folhas pecioladas a subsésseis, nervação broquidódroma. Inflorescência dicásios reduzidos a
2-3 flores. Cálice com lacínias iguais, sem coléteres na base. Corola infundibuliforme. Estames inclusos. Gineceu com ovário circundado por um disco nectarífero profundamente 5-lobado; cabeça do estilete similar a um carretel, com anel membranoso espesso na base. Folículos subparalelos, fusiformes, ápices geralmente divergentes. Sementes elípticas a lineares.

\section{Chave de identificação para as espécies de Rhabdadenia}

1. Lâmina foliar com ápice mucronado e base atenuada; tubo superior da corola campanulado, lobos brancos 18. Rhabdadenia biflora

1'. Lâmina foliar com ápice agudo e base cordada a auriculada; tubo superior da corola cilíndrico, lobos lilases. 19. Rhabdadenia madida

18. Rhabdadenia biflora (Jacq.) Müll. Arg., Fl. bras. 6(1): 1751860. Fig. 3a-g

Plantas volúveis, látex branco, ramos glabros. Folhas com pecíolo 1,0-2,3 cm compr., lâmina $4,8-11 \times 1,5-4,8 \mathrm{~cm}$, cartácea a membranácea, obovada, oblanceolada a elíptica, ápice mucronado, base atenuada, face adaxial glabra, face abaxial pubescente, nervuras secundárias em 13-17 pares. Inflorescência subterminal, 2 flora, raro 3 flora; pedúnculo 1-6 $\mathrm{cm}$ compr.; brácteas $2-3 \mathrm{~mm}$ compr., estreito-triangulares a lanceoladas, glabras. Pedicelo 0,6-3 cm compr. Cálice com lacínias 2-4 $\mathrm{mm}$ compr., lanceoladas a estreito-ovadas. Corola branca; tubo inferior 2-2,3 $\times 0,2-0,4 \mathrm{~cm}$, cilíndrico, tubo superior 1,2-1,8 $\times 1-2 \mathrm{~cm}$, campanulado, fauce amarela; lobos 1,3-1,6 0,8-2 cm, obovados, patentes. Estames inseridos no terço mediano do tubo; anteras 4-6 mm compr., dorso glabro com ápice piloso. Gineceu com ovário 1,8-2 mm compr.; disco nectarífero do mesmo tamanho do ovário; estilete 2-2,5 cm compr.; cabeça do estilete 1-2 $\mathrm{mm}$. Folículos 9-10 × 0,3-0,5 cm, cilíndricos. Sementes 2,3-3 cm compr., estreito-elíptica; coma $1,8-2 \mathrm{~cm}$ compr.

Material selecionado: Soure, Praia do Pesqueiro, 22.V.2011, fl., C.S. Costa et al. 510 (MG); PA-154 direção à Praia do Pesqueiro, 29.II.2012, fl. e fr., S.S. Viana et al. 70 (MG).

Espécie com amplo registro para as regiões Norte e Nordeste, principalmente em áreas de mangue (BFG 2015). Coletada com flores e frutos durante todo o ano, no entanto as flores são mais abundantes em períodos chuvosos (Morales 2009b). $\mathrm{Na}$ área de estudo foi coletada com flores também no período mais chuvoso de janeiro a maio e com frutos de novembro a janeiro, em beira de estrada, beira de rio e campo aberto, sendo que todas as áreas eram alagadas. A espécie é facilmente reconhecida pelas folhas conspicuamente pecioladas e pela corola branca com a parte superior do tubo campanulada.

19. Rhabdadenia madida (Vell.) Miers., Apocyn. S. Am. 121. 1878.

Fig. 3h-i

Plantas volúveis, látex incolor, ramos glabrescentes. Folhas com pecíolo 0,2-0,7 cm compr., lâmina 3-7,5 × 1,4-3,5 cm, membranácea, elíptica a estreito-elíptica, ápice agudo, base cordada a auriculada, faces adaxial e abaxial glabra a glabescente, nervuras secundárias em 11-14 pares. Inflorescência axilar, 2-flora; pedúnculo 2-4(7) $\mathrm{cm}$ compr.; brácteas $2,8-5 \mathrm{~mm}$ compr., esteitoovadas, glabrescentes. Pedicelo $0,8-1 \mathrm{~cm}$ compr. Cálice com lacínias 6-7 × 0,8-1 mm, lanceoladas a lineares. Corola lilás a roxa; tubo inferior $8-11 \times$ 1,5-2 mm, cilíndrico, tubo superior 2,5-3 $\times 1-15$ $\mathrm{cm}$, cilíndrico; lobos 1,6-2,4 × 1-2 cm, obovados, patentes. Estames inseridos no terço inferior do tubo; antera 5,1-6 mm compr., dorso glabro com ápice piloso. Gineceu com ovário 1,2-1,5 $\mathrm{mm}$ compr; disco nectarífero menor que o ovário; estilete 1,8-2,1 cm compr.; cabeça do estilete 2-2,2 $\mathrm{mm}$. Folículos 2,10-11,5 $\times 0,4-0,6 \mathrm{~cm}$, cilíndricos. Sementes 1,7-2,1 cm compr., lineares; coma 2-3 cm compr.

Material selecionado: Afuá, Rio Marajozinho, 12.IX.1992, fl., U.N. Maciel 1885 (MG); Muaná, Fazazenda São João, 28.VI.1962, fl. e fr., E. Oliveira 2081 (IAN).

Espécie de ampla distribuição, ausente apenas na região Nordeste (BFG 2015). Segundo Morales (2009b), floresce e frutifica durante todo o ano. Na área de estudo tem registro de floração em junho e 
novembro e frutificação em julho, em áreas sujeitas a alagamento. Rhabdadenia madida possui parte superior do tubo da corola cônico, com coloração lilás, características que geralmente a distinguem facilmente de $R$. biflora. Foi observada intensa variação quanta forma das folhas. Morales (2009b) ratifica esse polimorfismo também para as lacínias do cálice e hábito.

\section{Rauvolfioideae Kostel.}

Árvores, arbustos ou plantas volúveis, látex branco. Folhas opostas, alternas ou verticiladas, sem coléteres. Corola com pré-floração sinistrorsa. Estames com anteras com as tecas dispostas ao longo de toda a sua extensão e dorso não lignificado, não adnatas ao gineceu, pólen não agregado em polínias. Gineceu apocárpico a sincárpico; ovário súpero ou semi-ínfero, placentação marginal, axilar ou parietal. Frutos variados; sementes nuas, aladas ou ariladas.

20. Allamanda cathartica L., Mant. P1. 2: 214215. 1771 .

Plantas volúveis até $10 \mathrm{~m}$ alt. ou subarbustos até $0,5 \mathrm{~m}$ alt., e neste caso com ramos laterais eretos saindo próximos ao solo. Folhas verticiladas ou raro opostas, 2-6 por nó, pecíolo $0,2-0,8 \mathrm{~cm}$ compr., lâmina 7-14,5 × 1,8-4 cm, membranácea a subcoriácea, elíptica, estreito elíptica, oblanceolada a lanceolada, ápice acuminado a cuspidado, base atenuada, face adaxial glabra a glabrescente, face abaxial glabrescente com indumento concentrado sobre as nervuras, nervação broquidódroma, nervuras secundárias em 14-18 pares. Inflorescência bostricóide, 3-8(-12)-flora; pedúnculo 1,5-7 cm compr.; brácteas 2-4 mm compr., estreitotriangulares a lineares. Pedicelo 0,4-1 cm compr. Cálice com lacínias 5,9-13 mm compr., desiguais, lanceoladas, sem coléteres na base. Corola infundibuliforme, amarela; tubo inferior 2,5-3,5 $\times$ 0,2-0,4 cm, cilíndrico, reto a levemente curvado, tubo superior 1,4-4 × 1,3-2,5 cm, campanulado, com cinco tufos de tricomas supra-estaminais, fauce amarela; lobos 2,4-3 × 2-3 cm, oblíquoorbiculares, patentes. Estames inseridos no terço inferior do tubo; anteras 4,8-6 mm compr., dorso glabro. Gineceu com ovário 2-3 mm compr., súpero, sincárpico, placentação parietal; disco nectarífero levemente 5-lobado, menor que o ovário; estilete 2,4-3,5 cm compr.; cabeça do estilete 2,5 × 3,5 $\mathrm{mm}$ compr., constrita na região mediana, anel basal membranoso. Cápsula 3,7-6 × 3-5 cm, subglobosa a globosa, espinescente. Sementes $2-2,5 \times 1,7-2$ cm, elipticas a ovais, compressas; ala 4-6 mm raio. Material selecionado: Salvaterra, Praia Grande, 2.II.2012, fl. e fr., C.S. Costa 533, (MG); Prainha, 22.XII.2011, fl. e fr., S.S. Viana 6 (MG); Soure, PA-154, 29.II.2012, fl. e fr., S.S. Viana et al. 72 (MG).

Allamanda L. é um gênero representado por 15 espécies, das quais 13 ocorrem no Brasil (BFG 2015). Allamanda carthartica é uma espécie de ampla distribuição geográfica e largamente cultivada, presente em todas as regiões brasileiras (BFG 2015). São encontradas com flores e frutos em praticamente todo o ano. Ocorrem em regiões litorâneas, em geral na borda de mata, margens de rio, em solos úmidos ou secos (Sakane \& Shepherd 1981). Na região de estudo ocorre na borda de mata, margem de rio e áreas de vegetação secundária, crescendo como liana quando próximo a um suporte e como subarbusto de pequeno porte em dunas e ambiente aberto. Allamanda cathartica é popularmente conhecida como dor-de-dente, dedal-de-princesa, dedal-de-rainha e margarida. Segundo Sakane \& Shepherd (1981) há uma grande variabilidade no tamanho das flores e folhas, plasticidade também observadas nos espécimes coletados na área de estudo.

21. Ambelania acida Aubl., Hist. Pl. Guiane 1: 265-268, t. 104. 1775.

Árvores, 4-10 $\mathrm{m}$ de alt. Folhas opostas, pecíolo $0,8-1 \mathrm{~cm}$ compr., lâmina $11-18 \times 3,6-7$ $\mathrm{cm}$, cartácea, oblonga a elíptica, ápice cuspidado a agudo, base aguda a obtusa, glabra, nervação broquidódroma, nervuras secundárias em 18-20 pares. Inflorescência dicasial, axilar, 3-8-flora; pedúnculo 1-3 $\mathrm{mm}$; brácteas $1,8-2 \mathrm{~mm}$ compr., lanceoladas, glabras a glabrescentes. Pedicelo 1-2 mm compr. Cálice com lacínias 2,3-3 mm compr., desiguais, ovais, com numerosos coléteres opostos na base. Corola hipocrateriforme, branca; tubo inferior 3-4 × 2-3 mm, cilíndrico, tubo superior 5-6 × 2-3 mm, cilíndrico, fauce alva; lobos 8-10 $\times$ 3-4 mm, lanceolados, reflexos. Estames inseridos no terço inferior do tubo; anteras 5-7 mm compr., dorso glabro. Gineceu com ovário 5-6 mm compr., sincárpico, placentação axilar intrusiva; disco nectarífero ausente; estilete 1-1,5 mm compr.; cabeça do estilete 1,4-1,8 mm compr., cilíndrica, glabra, com anel basal espessado. Baga 3-5 × 2-3,5 $\mathrm{cm}$, elipsóide a oblonga. Sementes 5-6,3 × 3-4,3 mm, enrugadas, elipsóides.

Material selecionado: Curralinho, 8.IX.1971, fl., B. Ribeiro 169 (IAN); Rio Anajás, 28.X.1987, fr., H.T. Beck et al. 208 (MG). 
Ambelania Aubl. é representado por três espécies, todas ocorrentes no Brasil e concentradas na região Amazônica (Zarucchi 1987; BFG 2015). Ambelania acida é uma espécie distribuída amplamente na região Norte, chegando à região Nordeste (BFG 2015). Coletada com flores e fruto em março, abril e setembro a novembro, ocorrendo em mata de terra firme. A espécie é popularmente conhecida como pepino-do-mato e pepino-bravo, sendo consumida localmente in natura.

22. Hancornia speciosa Gomes, Mem. Math. Phis. Acad. Real Sci. Lisboa 2: 1, pl. 1. 1803.

Fig. 5g-o

Árvores, 4-8 $\mathrm{m}$ de alt. Folhas opostas, pecíolo 0,4-1 cm compr., lâmina 6,2-2,5 × 2,5-1,1 $\mathrm{cm}$, cartácea, elíptica, oblonga, lanceolada a oblanceolada, ápice agudo a cuspidado, base aguda, atenuada a cuneada, faces adaxial e abaxial glabras, nervação broquidódroma, nervuras secundárias em 34-58 pares, predominantemente paralelas entre si e perpendiculares à nervura primária. Inflorescência dicasial, terminal, 2-3-flora; pedúnculo 4-11 mm compr.; brácteas $0,2-0,4 \mathrm{~cm}$ compr., estreito-triangulares a lineares, glabras a pubescentes. Pedicelo 4-10 mm compr. Cálice com lacínias 20-30 mm compr., desiguais, ovais, sem coléteres na base. Corola hipocrateriforme, branca; tubo inferior 2,9-3,2 $\times 0,2-0,25 \mathrm{~cm}$, cilíndrico, tubo superior 5-6 × 3-4 mm, cilíndrico, fauce esverdeada; lobos 1,7-2 × 0,4-0,5 cm, oblíquolineares, reflexos a patentes. Estames inseridos no terço superior do tubo; anteras 2,5-3 mm compr., dorso glabro. Gineceu com ovário 1,3-2 mm compr., súpero, sincárpico, placentação parietal; disco nectarífero ausente; estilete 2,5-2,8 cm compr., cilíndrico, glabro; cabeça do estilete 2-2,5 mm compr., cilíndrica, base espessada. Baga 2-3 $\times 1,2-2,5 \mathrm{~cm}$, globosa. Sementes $1 \times 0,7 \mathrm{~cm}$, orbiculares a ovaladas.

Material selecionado: Salvaterra, Estrada para Água Boa, 28.II.2012,. fl. e fr., S.S. Viana et al. 65 (MG); Vila Marucá, 22.VII.2011, fl. e fr., S.S. Viana 5 (MG).

Hancornia Gomes é um gênero monotípico, distribuído principalmente em formações de cerrado, campo e campo rupestre de todas as regiões do Brasil. Ocorre espontaneamente desde a região Nordeste, em tabuleiros costeiros e baixadas litorâneas, até as regiões norte e sudeste em áreas de cerrado (Monachino 1945; Vieira Neto 1994; BFG 2015). Hancornia speciosa é uma espécie de ampla distribuição, presente em todas as regiões do Brasil, e que floresce e frutifica de novembro a fevereiro (Simões \& Kinoshita 2002; BFG 2015). Na região Norte, é pouco frequente e restrita a manchas de cerrado e campo misto, sendo encontrada com maior frequência na ilha do Marajó. Coletada com flores e frutos em praticamente todo o ano, no entanto o pico de produção, segundo Villachica et al. (1996) ocorre em março, setembro e novembro. Hancornia speciosa é conhecida popularmente por mangaba ou mangabeira, caracteriza-se por apresentar folhas com nervuras secundárias numerosas (34 a 58 pares), paralelas entre si, fruto bacáceo com manchas avermelhadas. O fruto é comestível e bastante utilizado na produção de sucos, sorvetes e consumo in natura (Vieira Neto 1994). Os espécimes coletadas apresentam pedúculo longo e folhas proporcionalmente menores, comparados com os que ocorrem no cerrado de centro-oeste, nordeste e sudeste do Brasil (Koch \& Kinoshita 1999; Simões \& Kinoshita 2002).

Himatanthus Willd. ex Schult. in Roemer \& Schult., Systema Vegetabilium 5: 221. 1819.

Árvores, látex abundante. Folhas alternas, congestas no ápice dos ramos, pecioladas a subsésseis, nervação broquidódroma. Inflorescência tipo cincício dicotômico, articulado; brácteas caducas, envolvendo duas flores e um eixo da inflorescência. Cálice com lacínias desiguais, podendo apresentar de uma a quatro reduzidas, sem coléteres na base. Corola hipocrateriforme. Estames inclusos. Gineceu sem disco nectarífero; ovário semi-ínfero, hemissincárpico, placentação axilar. Folículos subparalelos a divergentes. Sementes aladas, circulares, alas concêntricas.

Gênero com seis espécies no Brasil, exceto na região Sul (BFG 2015). As espécies de Himatanthus podem ser facilmente identificadas pelas folhas congestas no ápice, pelas inflorescências em cicinio dicotômico terminais, e pelas brácteas naviculares, robustas.

\section{Chave de identificação para espécies de Himatanthus}

1. Pecíolo 2-2,2 cm compr......

23. Himatanthus articulatus

1’. Pecíolo 0,3-1,4 cm compr. 24. Himatanthus drasticus 


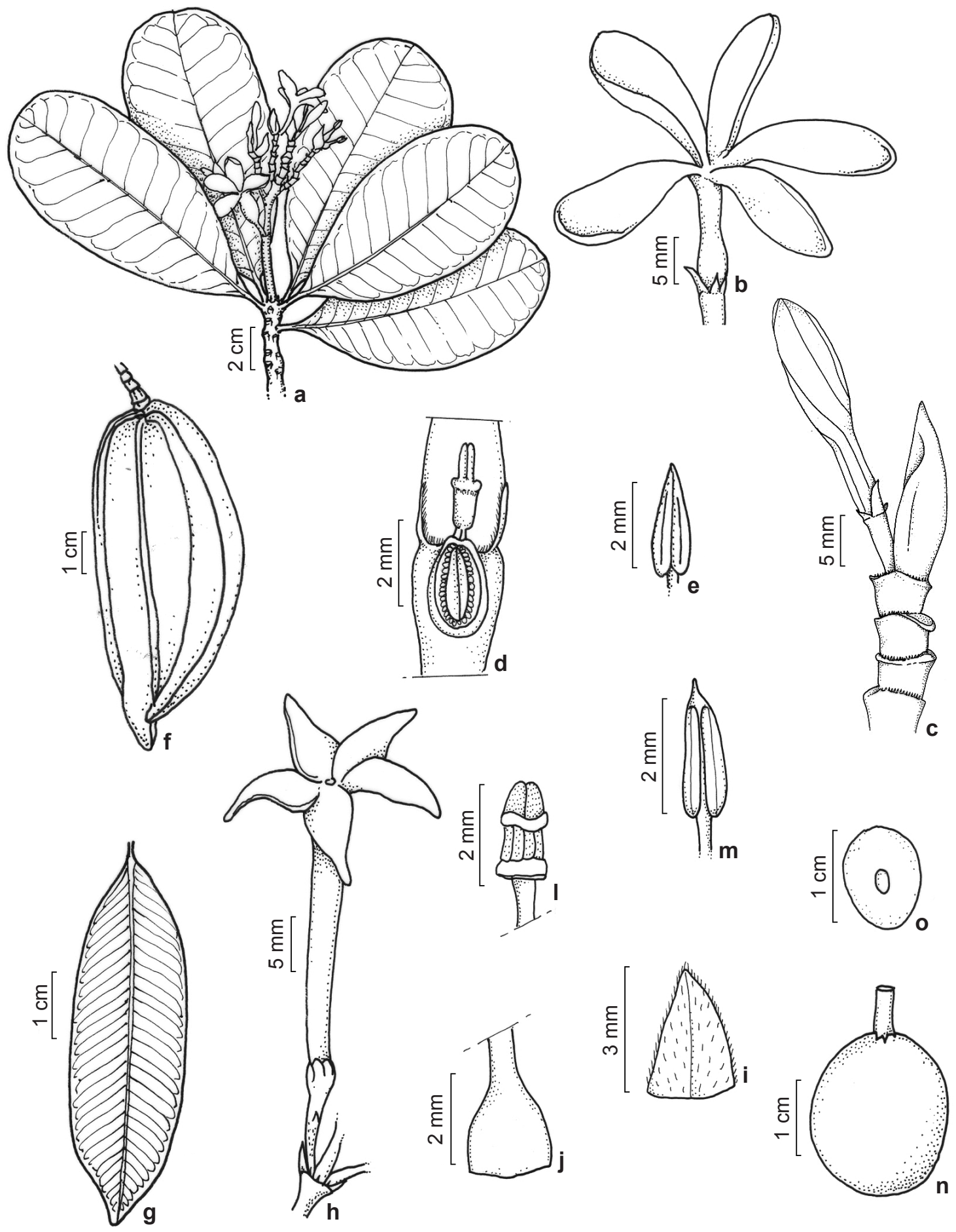

Figura 5 - a-f. Himatanthus drasticus (Mart.) Plumel - a. ramo florido; b. flor; c. parte da inflorescência com botão floral e bráctea; d. gineceu; e. antera; f. fruto. g-o. Hancornia speciosa Gomes - g. folha; h. flor; i. lacínia do cálice em vista abaxial; j. ovário; 1 . cabeça do estilete; m. antera em vista dorsal; n. fruto; o. semente. (a-e. Viana et al. 80; f. Ribeiro 193; g-o. Viana et al. 65).

Figure 5 - a-f. Himatanthus drasticus (Mart.) Plumel - a. flowering branch; b. flower; c. part of the inflorescence with flower bud and bract; d. gynoecium; e. anther; f. fruit. g-o. Hancornia speciosa Gomes - g. leaf blade; h. flower; i. abaxial surface of calyx lobe; j. ovary; 1. style head; m. anther in dorsal view; n. fruit; o. seed. (a-e. Viana et al. 80; f. Ribeiro 193; g-o. Viana et al. 65). 
23. Himatanthus articulatus (Vahl) Woodson., Ann. Missouri Bot. Gard. 25: 196-197, 193. 1938.

Árvores, (3)6-8(20) $\mathrm{m}$ de alt. Folhas com pecíolo 2-2,2 cm compr., lâmina 13-22 × 5-7 $\mathrm{cm}$, coriácea, raramente cartácea, obovada a oblanceolada, ápice agudo a arredondado, base aguda a arredondada, glabra, nervuras secundárias em 12-18 pares. Inflorescência terminal, 30-50 flora; pedúnculo 2-6 $\mathrm{cm}$ compr.; brácteas $1-1,8$ $\mathrm{cm}$, naviculares, glabras. Pedicelo $3-5 \mathrm{~mm}$ compr. Cálice com lacínias maiores com 2-3 mm compr., uma ou duas reduzidas $3-5 \mathrm{~mm}$ compr., estreito triangulares. Corola branca; tubo inferior $2-3 \times$ 2,5-4 mm, cilíndrico, tubo superior 9-10 $\times 2-3$ $\mathrm{mm}$, cilíndrico, fauce amarela; lobos 13-20 × 7-10 $\mathrm{cm}$, oblanceolados a elípticos, reflexos. Estames inseridos no terço inferior do tubo; anteras 2,3-3 $\mathrm{mm}$ compr., dorso pubescente. Gineceu com ovário $2 \mathrm{~mm}$ compr.; estilete 1-2 mm compr., cilíndrico; cabeça do estilete $2,3 \mathrm{~mm}$ compr., obcônica. Frutos e sementes não observados.

Material selecionado: Muaná, 2.XI.2011, fl., S.S. Viana et al. 35 (MG, IAN); Salvaterra, Cachoerinha, 22.VII.12011, fl., S.S. Viana 3 (MG, UEC).

Espécie restrita às regiões Norte e Nordeste (BFG 2015). Segundo Spina (2004) floresce e frutifica em praticamente todos os meses do ano, sendo que na região de estudo foi coletada com flores em julho, outubro e novembro. A espécie foi encontrada em áreas de campo misto $\mathrm{e}$ capoeira, e é muito utilizada pela população local para fins medicinais. Himatanthus articulatus, popularmente conhecida como sucuúba, é muito semelhante a $H$.drasticus (Mart.) Plumel, espécie da qual difere somente em características vegetativas como o tamanho do pecíolo, que pode variar de $2-2,2 \mathrm{~cm}$ em $H$. articulatus mas que não ultrapassa $1,4 \mathrm{~cm}$ em $H$. drasticus. Embora Spina (2004) aponte o padrão de nervação mista bronquidódroma-eucampidódroma como característica diagnóstica, este não foi observado nos espécimes da Ilha do Marajó, nem mesmo em folhas diafanizadas.

24. Himatanthus drasticus (Mart.) Plumel., Compt. Rend. Séances Soc. Biogéogr. 66(3): 108. 1990.

Fig. 5a-f

Árvores, 3-12 m de alt. Folhas com pecíolo 0,3-1,4 cm compr., lâmina 10-19 × 5-9 cm, coriácea, obovada a oblanceolada, ápice agudo a arredondado, base aguda a arredondada, faces adaxial e abaxial glabras, nervuras secundárias em 12-20 pares. Inflorescência terminal, 27-50 flora; pedúnculo $2-5 \mathrm{~cm}$ compr.; brácteas $1-2$ $\mathrm{cm}$, naviculares, glabras. Pedicelo 3-4 mm compr. Cálice com lacínias maiores com 3-5 $\mathrm{mm}$ compr., uma ou duas reduzidas, $2-2,5 \mathrm{~mm}$ compr., estreito triangulares. Corola branca; tubo inferior $2 \times 3 \mathrm{~mm}$, cilíndrico, tubo superior 8-9 $\times 2-3,2 \mathrm{~mm}$, cilíndrico, fauce amarela; lobos $12-19 \times 7-11 \mathrm{~cm}$, oblanceolados a elípticos, reflexos. Estames inseridos no terço inferior do tubo; anteras 2,3-3 mm compr., dorso pubescente. Gineceu com ovário 2-25 mm compr.; estilete 1-2 mm compr., cilíndrico; cabeça do estilete 2 mm compr., obcônica. Folículos 3-25 × 2-3,5 $\mathrm{cm}$, subparalelos. Sementes 2,5-3 × 1,5-2 cm, estriadas, elípticas, compressas, ala $1-2,5 \mathrm{~cm}$ raio. Material selecionado: Soure, Camará, 29.II.201, fl., S.S. Viana et al. 80 (MG, IAN); Salvaterra, Estrada para Cachoeira do Ararí, 28.II.2012, fl. e fr., S.S. Viana et al. 66 (MG, IAN, UEC, SP).

Espécie de ampla distribuição geográfica em território brasileiro, exceto na região Sul (BFG 2015). Segundo Spina (2004) floresce e frutifica em praticamente todos os meses do ano, sendo que na região de estudo foi coletada com flores de setembro a janeiro e com frutos em agosto e outubro. A espécie foi encontrada em campo misto e capoeira e borda de mata. Himatanthus drasticus, popularmente conhecido como janaúba ou tiborna, assemelha-se a $H$. articulatus, sendo diferenciado através do pecíolo menor. Exemplares de ambas as espécies foram analisados, e não se observou nenhuma característica morfológica adicional para diferenciá-las além do tamanho do pecíolo. Este fato sugere que, ao menos na ilha do Marajó, os caracteres diagnósticos apontados por Spina (2004) se sobrepõem em sua maioria e não são suficientes para um reconhecimento inequívoco entre as duas espécies, necessitando de uma reavaliação.

Lacmellea H.Karst., Linnaea 28: 449. 1856 [1857]. Árvores ou arbustos. Folhas opostas, pecioladas a subsésseis, nervação broquidódroma. Inflorescência corimbosa a umbeliforme, axilar. Flores actinomorfas a zigomorfas. Cálice com lacínias desiguais, sem coléteres na base. Corola hipocrateriforme. Estames inclusos. Gineceu com disco nectarífero concrescido ao ovário ou ausente, sincárpico; ovário súpero, placentação parietal; cabeça do estilete cilíndrica. Baga com a base do estilete persistente formando uma projeção espinescente. Sementes compresso-elípticas, nuas.

O gênero é representado por 25 espécies. Destas, 12 ocorrem no território brasileiro, principalmente na região Amazônica (BFG 2015). 


\section{Chave de identificação para espécies de Lacmellea}

1. Árvores; folhas cartáceas, sem pontuações; inflorescência congesta; brácteas com coléteres; flores actinomorfas, não curvadas no ápice; lobos da corola pubescentes .................25. Lacmellea aculeata

1'. Arbustos; folhas coriáceas, com pontuações; inflorescência laxa; brácteas sem coléteres; flores zigomorfas, curvadas no ápice; lobos da corola glabros. 26. Lacmellea densifoliata

25. Lacmellea aculeata (Ducke) Monach., Lloydia 7(4): 292. 1944. [1945].

Fig. 6a-f

Árvores, 4,5-18 m alt. Folhas com pecíolo 0,5-0,9 cm compr., lâmina 10-17 × 4-7 cm, cartácea, glabra, elíptica a ovada, ápice agudo a cuspidado, base obtusa, glabra, nervuras secundárias em 11-12 pares. Inflorescência corimbosa, congesta, 6-14-flora; pedúnculo 4-9 mm compr.; brácteas 1,8-2,3 mm compr, triangulares, pubescentes, com coléteres na base. Flores actinomorfas; pedicelo 2-5 mm compr. Cálice com lacínias 2,3-3,4 mm compr., ovais. Corola branca; tubo inferior $24-28$ $\times 1,8-2 \mathrm{~mm}$, cilíndrico, tubo superior 5-7 $\times 2,5-3$ $\mathrm{mm}$, cilíndrico, fauce branca; lobos 4-5 $\times 2-2,8 \mathrm{~mm}$, ovados a elípticos, reflexos a patentes, pubescentes. Estames inseridos no terço superior do tubo; anteras 7-8 mm compr., dorso glabro. Gineceu com ovário 2-3 mm compr., disco nectarífero ausente; estilete 0,5-0,7 mm compr.; cabeça do estilete $2,6 \mathrm{~mm}$ compr., cilíndrica. Baga 1-1,8 $\times 1,3-1,5 \mathrm{~cm}$, globosa. Sementes não observadas.

Material selecionado: Muaná, Desterro, 3.VI.2011, fr., S.S. Viana et al. $44(\mathrm{MG})$.

Espécie presente nas regiões Norte, Nordeste e Centro-Oeste (BFG 2015). São encontradas com flores em praticamente todos os meses do ano. $\mathrm{Na}$ região de estudo foi coletada com fruto em junho, em borda de mata de terra firme. Lacmellea aculeata, popularmente conhecida como pau-de-colher, apresenta hábito arbóreo, inflorescência congesta, flores com tubo da corola longo, folhas cartáceas e flores actinomorfas, o que a diferencia de $L$. densifoliata (Ducke) Markgr., espécie que apresenta inflorescência laxa, flores com tubo da corola curto, folhas coriáceas e flores zigomorfas.

26. Lacmellea densifoliata (Ducke) Markgr., Notizbl. Bot. Gart. Berlin-Dahlem 15(4): 624. 1941.

Fig. 6g-h

Arbustos, 4-5 m de alt. Folhas com pecíolo 0,3-0,7 cm compr., lâmina 3,5-6 × 2,5-4,5 cm, coriácea, glabra, com pontuações, amplamente elíptica a ovada, ápice arredondado a obtuso, base arredondada, glabra, nervuras secundárias em 10-11 pares. Inflorescência corimbosa, laxa, 6-14-flora; pedúnculo 2-3 mm compr.; brácteas $1,8-2,3 \mathrm{~mm}$ compr., triangulares, pubescentes, margem ciliada, sem coléteres na base. Flores zigomorfas, curvadas no ápice; pedicelo 3-3,4 mm compr. Cálice com lacínias 1,8-2 mm compr., ovais. Corola branca; tubo inferior 24-28 $\times 1,8-2 \mathrm{~mm}$, cilíndrico, tubo superior 6-8 $\times 2,4-3 \mathrm{~mm}$, cilíndrico, curvado no ápice, fauce alva; lobos 3-4 × 1,8-2 mm, ovados a elípticos, patentes a reflexos, glabros. Estames inseridos no terço superior do tubo; anteras 3-4 mm compr., dorso glabro. Gineceu com ovário 1-1,53 mm compr.; disco nectarífero concrescido ao ovário; estilete 0,3-0,4 mm compr.; cabeça do estilete 1,3-1,5 mm compr., cilíndrica. Baga 0,8-1,3×0,8-1 cm, globosa. Sementes não observadas.

Material selecionado: Cachoeira do Ararí, Fazenda Inajatuba, 2.XII.1969, fr., S.P. Bento 181 (IAN); São Sebastião da Boa Vista, 14.IX.1971, fl., S.P. Bento 245 (IAN); Muaná, Fazenda Espírito Santo, 25.X.1970, fr., S.P. Bento 245 (IAN).

Espécie com registro para a região Norte, coletada apenas no estado do Pará (BFG 2015). Na área de estudo, foi coletada com flores em maio, setembro, outubro e dezembro e com fruto em janeiro, abril e outubro, em áreas de cerrado.

27. Macoubea guianensis Aubl., Hist. Pl. Guiane 2(Suppl.): 18, t. 378. $1775 . \quad$ Fig. 7a-i

Árvores, 18-20 m de alt.; ramos com coléteres inter e intrapeciolares, encobertos pela extensão da base do pecíolo que contorna o ramo formando um anel. Folhas opostas, pecíolo 1,3-2,5 cm compr., lâmina 13-29 × 6-13 cm, cartácea, elíptica a obovada, ápice arredondado a agudo, base aguda, face adaxial glabrescente, face abaxial pubescente a velutina, nervação craspedódroma, nervuras secundárias em 14-16 pares. Inflorescência corimbosa, terminal, 30 40 flora; pedúnculo $1-2,5 \mathrm{~cm}$ compr. e pedúnculos de segunda e terceira ordem, $0,3-0,9 \mathrm{~mm}$ compr.; brácteas 2-4 mm compr., naviculares, glabras. Pedicelo 0,3-0,9 mm compr. Cálice com lacínias 2,8-3,2 mm compr., iguais, ovais, com coléteres na base. Corola hipocrateriforme, alva; tubo inferior 2-3 $\times 2,5-3 \mathrm{~mm}$, cilíndrico, tubo superior 4,4-5,8 $\times 3-3,8 \mathrm{~mm}$, cilíndrico, fauce alva; lobos $1,2-1,4$ $\times 0,6-0,8 \mathrm{~mm}$, ovados a lanceolados, patentes. Estames inseridos na terço inferior do tubo; anteras 


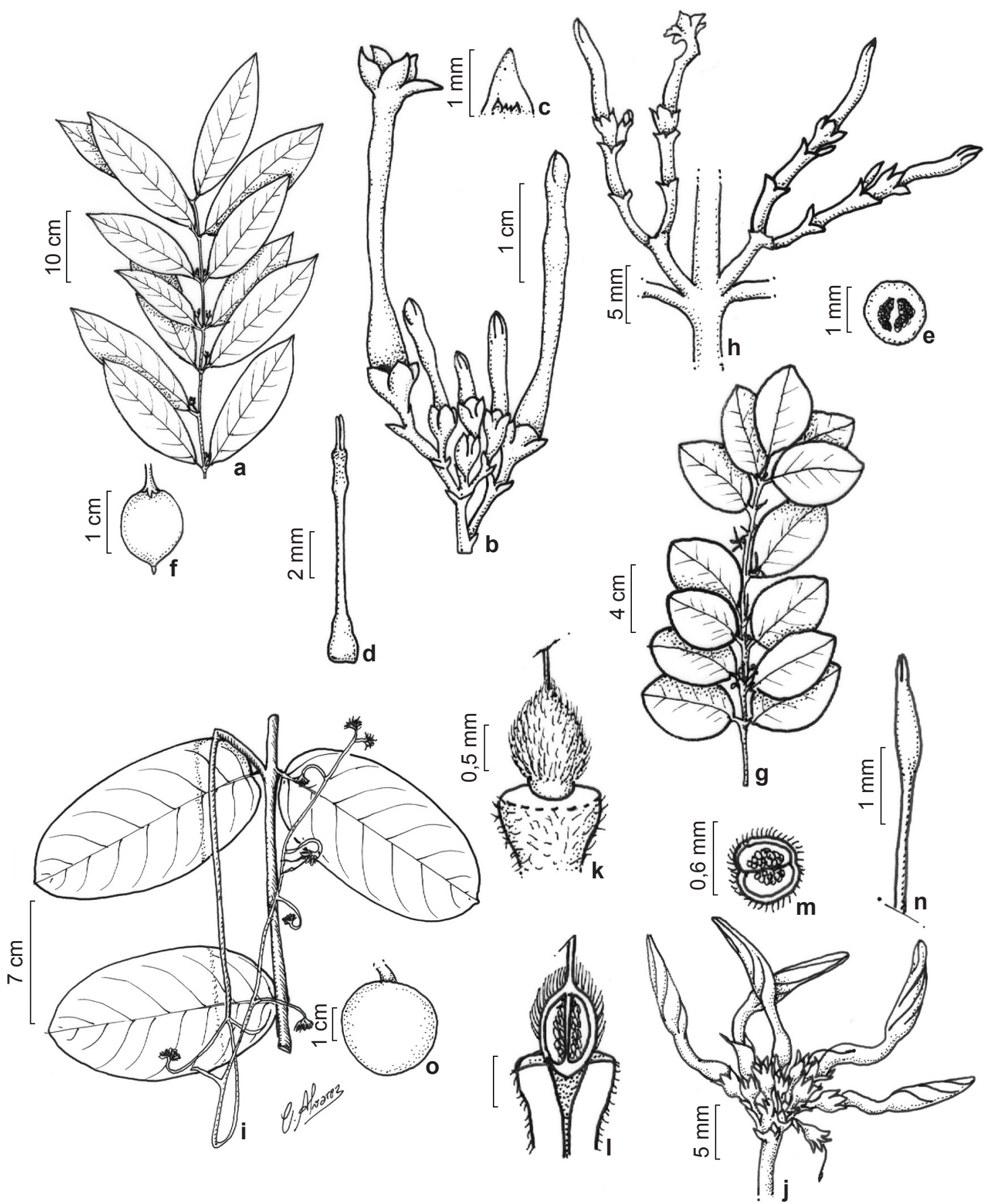

Figura 6 - a-f. Lacmellea aculeata (Ducke) Monach. - a. ramo florido; b. inflorescência; c. bráctea em vista adaxial; d. gineceu; e. ovário, corte transversal; f. fruto. g-h. L. densifoliata (Ducke) Markgr. - g. ramo florido; h. inflorescência. i-o. Pacouria boliviensis (Markgr.) A. Chev - i. ramo florido; j. inflorescência; k. ovário; 1. ovário em corte longitudinal; m. ovário em corte transversal; n. cabeça do estilete; o. fruto. (a. Viana et al. 44; b-f. Pires 10225; g-h. Bento 245; i-o. Maciel 1933).

Figure 6 - a-f. Lacmellea aculeata (Ducke) Monach. - a. flowering branch; b. inflorescence; c. adaxial surface of bract; d. gynoecium; e. ovary in cross section; f. fruit. g-h. L. densifoliata (Ducke) Markgr. - g. flowering branch; h. inflorescence. i-o. Pacouria boliviensis (Markgr.) A. Chev - i. flowering branch; j. inflorescence; k. ovary; 1. ovary in longitudinal section; $\mathrm{m}$. ovary in cross section; n. style head; o. fruit. (a. Viana et al. 44; b-f. Pires 10225; g-h. Bento 245; i-o. Maciel 1933). 
4-5 mm compr., dorso glabro. Gineceu com ovário 2-2,3 mm compr., súpero, apocárpico, pubescente, tetragonal, placentação marginal; disco nectarífero ausente; estilete 0,7-0,9 mm compr.; cabeça do estilete 1,8-2 mm compr., cônico-alongada, com anel basal espessado. Baga 7-8,5 × 6,8-8 cm, globosa, pericarpo lignificado. Sementes $1,4-1,8 \times 0,4-0,5$ $\mathrm{cm}$, enrugadas, oblongas, não aladas, recobertas por substância incolor viscosa.

Material selecionado: Muaná, Rio Pitauan, 3.XI.2011, fr., S.S. Viana et al. 53 (MG).

O gênero é representado por três espécies, duas das quais ocorrem no Brasil (BFG 2015). Macoubea guianensis apresenta distribuição disjunta, ocorrendo tanto na região Amazônica quanto na Mata Atlântica (BFG 2015). Floresce em maio e setembro, e frutifica em novembro e outubro. $\mathrm{Na}$ área de estudo foi coletada apenas com frutos em novembro, em mata de terra firme. A espécie é popularmente conhecida como amapá-doce, possui frutos grandes, secos, com sementes crenuladas, inflorescência multiflora com pecíolos de segunda e terceira ordem. Na área de estudo, M. guianensis é facilmente distinta das demais coletadas pelo ovário com forma tetragonal e pelas sementes oblongas, recobertas por substância incolor viscosa.

28. Pacouria boliviensis (Markgr.) A. Chev., Rev. Int. Bot. Appl. Agric. Trop. 28: 455. 1948.

Fig. 6i-o

Plantas volúveis de grande porte; ramos lanosos. Folhas opostas, pecíolo $0,5-0,8 \mathrm{~cm}$ compr.; lâmina 13-17 × 7,5-8,6 cm, coriácea, elíptica, amplamente elíptica a lanceolada, ápice arredondado a agudo, base arredondada, face adaxial pilosa a glabrescente, face abaxial vilosa a lanosa, nervação broquidódroma, nervuras secundárias em 11-12 pares. Inflorescência umbeliforme, axilar, 10-25 flora, com as terminações geralmente transformadas em gavinhas; pedúnculo 1-6 cm compr.; brácteas 1-1,2 mm compr., triangulares, lanosas. Pedicelo 1-3 mm compr. Cálice com lacínias 2-2,5 mm compr., iguais, estreito-triangulares a lanceoladas, sem coléteres na base. Corola hipocrateriforme, amarelada; tubo inferior 3-4,5 × 1-2 mm, cilíndrico, tubo superior 3-5× 1-1,8 mm, cilíndrico; lobos 8-10 $\times 2,5-3,5 \mathrm{~mm}$, lineares, reflexos. Estames inclusos no terço inferior do tubo; anteras 1,8-2,2 mm compr., dorso glabro. Gineceu com ovário 1-1,4 mm compr., súpero, sincárpico, densamente piloso, lignificado, placentação parietal; disco nectarífero ausente; estilete 2-2,5 mm compr.; cabeça do estilete 1,5-1,8 $\mathrm{mm}$ compr., cilíndrica, base levemente alargada.
Baga 3,9-4,8 × 3-4,5 cm, subglobosa. Sementes não observadas.

Material selecionado: Afuá, Rio Marajozinho, 2.X.1992, fr., U.N. Maciel 1353 (MG); Rio Cajuuna, 12.IX.1992, fl., U.N. Maciel 1933 (MG).

Gênero com três espécies, todas estas ocorrendo no Brasil (BFG 2015). Pacouria boliviensis possui registros para a região Norte e Nordeste (BFG 2015), sendo que na área de estudo foi encontrada com flores e frutos em novembro em mata de várzea. A espécie é muito similar morfologicamente à $P$. guianensis Aubl., tanto em características vegetativas quanto reprodutivas, diferindo desta por apresentar os lobos da corola com apenas um dos lados densamente recoberto por tricomas longos (Monachino 1945).

29. Parahancornia fasciculata (Poir.) Benoist, Arch. Bot. Mém. 5: 274. 1933.

Árvores, 10-40 m alt. Folhas opostas, pecíolo 1,3-2,5 cm compr., lâmina 13-29 × 6-13 cm, cartácea, elíptica a oblonga, ápice acuminado, base aguda, glabra, nervação broquidódroma, nervuras secundárias em 14-16 pares. Inflorescência corimbiforme, terminal, 12-35 flora; pedúnculo $1-2,5 \mathrm{~cm}$ compr., pedúnculos de segunda e terceira ordem, 0,3-0,9 mm compr.; brácteas 1,8-4 mm compr., naviculares, glabras. Pedicelo 3-0,9 mm compr. Cálice com lacínias 2,8-3,2 mm compr., iguais, ovais, sem coléteres na base. Corola hipocrateriforme, alva; tubo inferior $2-3 \times 2,5-3$ $\mathrm{mm}$, cilíndrico, tubo superior 4,4-5,8 $\times 3-3,8 \mathrm{~mm}$, cilíndrico, fauce alva; lobos $1,2-1,4 \times 0,6-0,8 \mathrm{~mm}$, ovais a lanceolados, suberetos a patentes. Estames inseridos na parte inferior do tubo; anteras 4-5 $\mathrm{mm}$ compr., dorso glabro. Gineceu com ovário 2-2,3 mm compr., súpero, sincárpico, pubescente, placentação parietal; disco nectarífero ausente; estilete 0,7-0,9 mm compr.; cabeça do estilete 1,8-2 mm compr., globosa, pubescente. Baga 7-8,5 $\times 6,8-8 \mathrm{~cm}$, globosa. Sementes $1,4-1,8 \times 0,4-0,5$ $\mathrm{cm}$, oblongas, não comosas.

Material selecionado: Muaná, Rio Anabijú, 2.XI.2011, fr., S.S. Viana et al. 38 (MG).

Parahancornia Ducke possui sete espécies restritas à região Amazônica e todas com registro de coleta para o Brasil (Zarucchi 1991; BFG 2015). Parahancornia fasciculata ocorre na região Norte, nos estados de Amazonas, Pará e Rondônia, floresce em abril, junho, agosto e dezembro e frutifica em janeiro, outubro e dezembro (BFG 2015). Na região de estudo foi coletada apenas com fruto, em janeiro e novembro. Parahancornia fasciculata é popularmente conhecida como amapá 


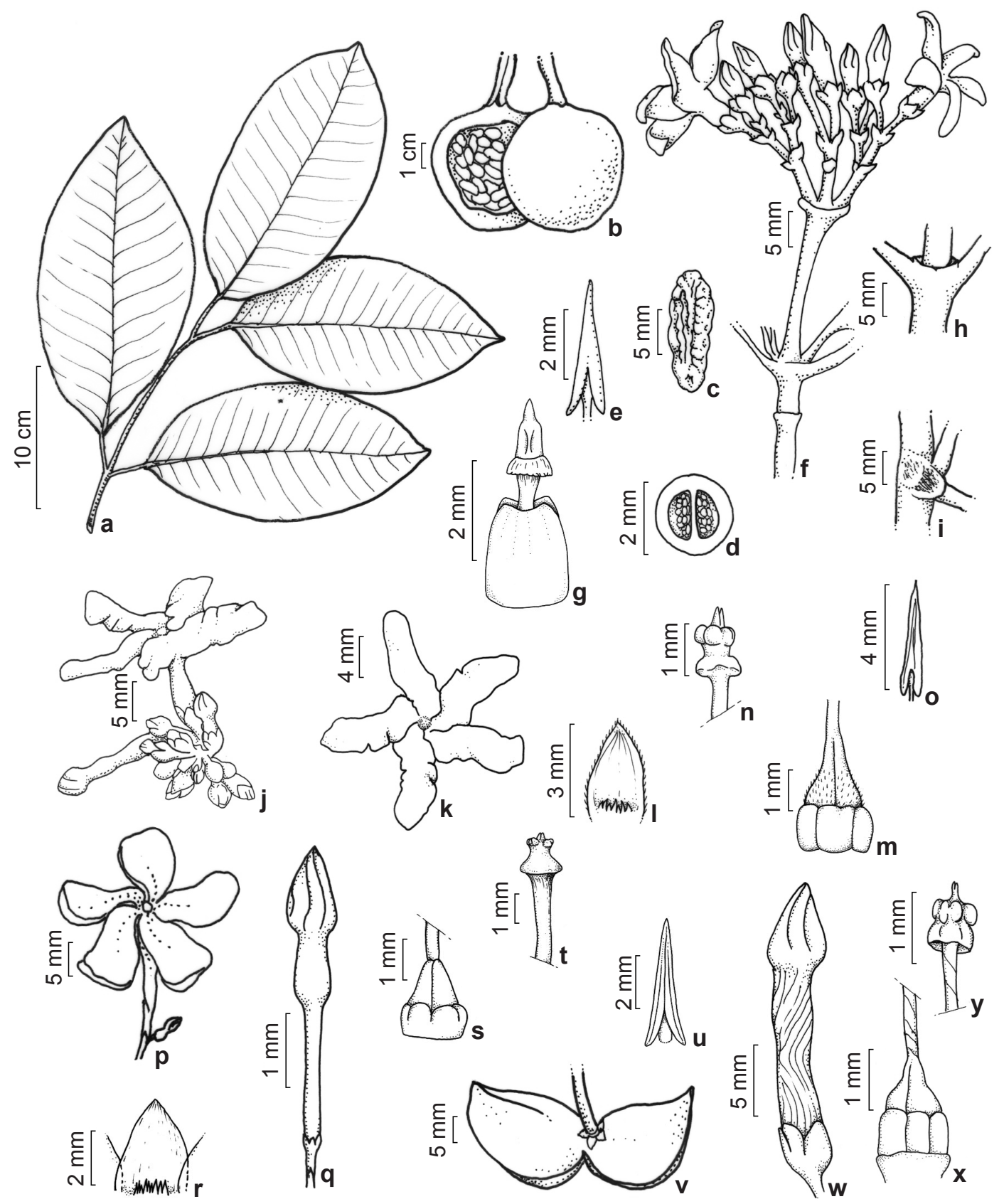

Figura 7 - a-i. Macoubea guianensis Aubl. - a. ramo estéril; b. fruto; c. semente; d. ovário em corte transversal; e. antera vista dorsal; f. inflorescência; g. gineceu; h. região nodal; i. coléteres na axila do pecíolo. j-o. Tabernaemontana angulata Mart. ex Müll. Arg. - j. inflorescência; $\mathrm{k}$. flor vista frontal; 1 . lacínia face adaxial; m. ovário com disco nectarífero; $\mathrm{n}$. cabeça do estilete; o. antera vista dorsal. p-v. T. flavicans Willd. ex Roem. \& Schult. - p. flor; q. botão floral; r. lacínia face adaxial, evidenciando os coléteres; s. ovário com disco nectarífero; t. cabeça do estilete; u. antera, vista dorsal; v. fruto. w-y. T. siphilitica (L. f.) Leeuwenb. - w. botão; x. ovário com disco nectarífero e o estilete retorcido; y. cabeça do estilete. (a-c. Viana et al. 53; d-i. Oliveira 2599; i-o. Costa et al. 535; p-v. Viana et al. 37; w-t. Salomão 1264).

Figure 7 - a-i. Macoubea guianensis Aubl. - a. sterile branch; b. fruit; c. seed; d. ovary in cross section; e. anther in dorsal view; f. inflorescence; g. gynoecium; h. nodal region; i. colleters at the axil of the petioles. j-o. Tabernaemontana angulata Mart. ex Müll. Arg. - j. inflorescence; $\mathrm{k}$. flower in frontal view; l. adaxial surface of calyx lobe; $\mathrm{m}$. ovary with nectary disk; $n$. style head; o. anther in dorsal view. p-v. T. flavicans Willd. ex Roem. \& Schult. - p. flower; q. flower bud; r. adaxial surface of calyx lobe; s. ovary with nectary disk; t. style head; u. anther in dorsal view; v. fruit. w-y. T. siphilitica (L. f.) Leeuwenb. - w. flower bud; x. ovary with nectary disk and twisted style; y. style head. (a-c. Viana et al. 53; d-i. Oliveira 2599; i-o. Costa et al. 535; p-v. Viana et al. 37; w-t. Salomão 1264). 
ou amapazeiro. O látex da espécie é considerado medicinal pelas populações locais, sendo utilizado na preparação de chás, garrafadas ou unguentos. Quando em floração, a espécie perde parte das folhas, expondo as inflorescências portando flores cuja corola desprende-se ao menor contato.

\section{Spongiosperma grandiflorum (Huber)} Zarucchi, Agric. Univ. Wageningen Pap. 87(1): 53. 1987[1988].

Árvores, 4-6 m de alt.; ramos com linhas ou cristas interpeciolares conspícuas. Folhas opostas, pecíolo 0,7-1 cm compr., lâmina $12-22 \times 5,5-9,5$ $\mathrm{cm}$, coriácea a subcoriácea, oblonga a lanceolada, ápice agudo a cuspidado, base obtusa, glabra, nervação broquidódroma, nervuras secundárias em 30-39 pares. Inflorescência corimbiforme, terminal ou axilar, 6-18 flora; pedúnculo 9-2,5 cm compr.; brácteas 1-1,8 mm compr., ovais, glabras. Pedicelo 4-12 mm compr. Cálice com lacínias 3-5 mm comp., desiguais, ovais, sem coléteres na base. Corola hipocrateriforme, branca; tubo inferior 4-8 $\times 7-8 \mathrm{~mm}$ cilíndrico, tubo superior $15-19 \times 4-6$ $\mathrm{mm}$, cilíndrico, fauce alva; lobos $3-4 \times 0,8-1,5 \mathrm{~cm}$, estreito-elípticos a oblongos, suberetos a reflexos. Estames inseridos no terço inferior do tubo; anteras 7-9 mm compr., dorso glabro. Gineceu com ovário 3-4 mm compr., súpero, sincárpico, glabro, placentação parietal intrusiva; disco nectarífero ausente; estilete 3-4 mm compr.; cabeça do estilete 20-25 mm compr., cilíndrica, base com anel espessado. Baga 6-8 $\times 2,5-3,5 \mathrm{~cm}$, elipsoide, esponjosa. Sementes 9-13 × 3-5 mm, crenuladas, superfície esponjosa, elípsoides a ovadas, nuas. Material selecionado: Muaná, Rio Urubú, 4.XI.12011, fl. e fr., S.S. Viana 55 (MG).

Spongiosperma Zarucchi possui seis espécies, das quais três ocorrem no Brasil, predominantemente na região Amazônica, com algumas alcançando o Nordeste brasileiro. (Zarucchi 1987; BFG 2015). Spongiosperma grandiflorum tem ocorrência nas regiões Norte e Nordeste (BFG 2015). A espécie floresce e frutifica em janeiro, abril, março, julho, outubro, novembro e dezembro, sendo que na área de estudo foi coletada com flor e com fruto em novembro, em mata de várzea. A espécie é popularmente conhecida como pepino-de-várzea e angélica-do-igapó, sendo este o primeiro registro para a ilha do Marajó. Diferentemente das outras espécies do gênero, observamos espécimes no campo como indivíduos solitários, e nunca formando grandes populações (Zarucchi 1987). Devido às pequenas diferenças morfológicas entre as espécies do gênero, a maioria destas relacionada ao número de flores por inflorescência, dimensões do tubo da corola e forma dos frutos, a identificação foi complementada a partir de dados sobre sua área de ocorrência. Spongiosperma grandiflorum registro é conhecida para os estados do Pará, Amapá e Maranhão, enquanto S. longilobum (Markgr.) Zarucchi e S. macrophyllum (Müll.Arg.) Zarucchi tem ocorrência restrita no Estado do Amazonas (Zarucchi 1987).

Tabernaemontana L., Sp. P1. 1: 210. 1753.

Arbustos, ramos cilíndricos a angulosos. Folhas opostas, geralmente em pares desiguais, com região basal alargada formando ócrea, nervação broquidódroma. Inflorescência corimbiforme a dicasial. Cálice com coléteres opostos na base. Corola hipocrateriforme. Estames inclusos. Gineceu com disco nectarífero; ovário súpero, apocárpico, placentação marginal. Folículos divergentes, lisos ou muricados. Sementes elípticas, ariladas; arilo amarelado, alaranjado ou avermelhado.

Maior gênero de Rauvolfioideae possui distribuição pantropical e cerca de 120 espécies, das quais 30 ocorrem no Brasil (Simões et al. 2010; BFG 2015). As espécies de Tabernaemontana são reconhecidas por apresentar ramificações dicotômicas e folhas em geral em pares desiguais (Leeuwenberg 1994).

\section{Chave de identificação para espécies de Tabernaemontana}

1. Ramos cilíndricos; folhas cartáceas a subcartáceas; cálice com lacínias glabras; disco nectarífero levemente 5-lobado.... 32. Tabernaemontana flavicans

1'. Ramos angulosos; folhas coriáceas a subcoriáceas; cálice com lacínias pubescentes; disco nectarífero profundamente 5-lobado

2. Cálice com lacínias iguais; ovário pubescente; estilete cilíndrico; estames inseridos no terço superior do tubo da corola 31. Tabernaemontana angulata

2'. Cálice com lacínias desiguais; ovário glabro; estilete retorcido; estames inseridos no terço mediano do tubo da corola 33. Tabernaemontana siphilitica 
31. Tabernaemontana angulata Mart. ex Müll. Arg., Fl. bras. 6(1): 72. 1860 . Fig. 7j-o

Arbusto, 0,5-3 m de alt.; ramos angulosos. Folhas com pecíolo 2-4 $\mathrm{mm}$ compr., lâmina $12-26,3 \times 3,5-10 \mathrm{~cm}$, coriácea, elíptica ou estreitoelíptica, ápice agudo a cuspidado, base cuneada, face adaxial glabra, face abaxial pubescente com pontuações regulares, nervuras secundárias em 13-15 pares. Inflorescência corimbiforme, axilar, 9-18 flora; pedúnculo 0,8-3 cm comp.; brácteas 2-3 mm compr., ovadas, glabras a pubescentes. Pedicelo 2-3 mm compr. Cálice com lacínias 2-4 $\mathrm{mm}$ compr., iguais, ovais, pubescentes. Corola branca a rosada; tubo inferior $1,2-1,4 \times 0,2-0,3$ $\mathrm{cm}$, cilíndrico, tubo superior $6-5 \times 2,1-2,8 \mathrm{~mm}$, cilíndrico, fauce alva a rosada; lobos 1,4-1,6 $\times$ 0,6-0,8 cm, oblongos a falciformes, patentes. Estames inseridos no terço superior do tubo; anteras 4-4,3 mm compr., dorso glabro Gineceu com ovário, 2,5-4 mm compr., pubescente; disco nectarífero profundamente 5-lobado com metade do comprimento do ovário; estilete 9-14 mm compr., glabro; cabeça do estilete 1-1,5 mm compr., similar a um carretel, anel basal recurvado. Folículos 2,5-3,5 × 1,4-1,8 cm, obliquamente elipsoides. Sementes 6-10 × 2-3 mm, crenuladas, oblíquas a estreitamente elipsoides, com sulcos longitudinais; arilo amarelado.

Material selecionado: Muaná, Rio Anabijú, 2.VII.1962, fl. e fr., E. Oliveira 2109 (IAN); Salvaterra, estrada em direção à Cachoeira do Ararí, 2.III.2012, fl., C.S. Costa et al. 535 (MG, IAN).

Espécie com registro de coleta para a região Norte e Nordeste (BFG 2015). Segundo Leeuwenberg (1994), floresce e frutifica ao longo de todo o ano, com pico em junho e julho. Na área de estudo foi coletada com flores em fevereiro, abril, julho e outubro, e com frutos em abril, em borda de mata e capoeira. Tabernaemontana angulata assemelha-se à $T$. siphilitica (L.f.) Leeuwenb., podendo ser diagnosticada por apresentar corola com lacínias iguais, ovário pubescente, estilete cilíndrico e estames inseridos no terço superior do tubo da corola, enquanto $T$. siphilitica possui corola com lacínias subiguais, ovário glabro, estilete marcadamente retorcido e estames inseridos no terço mediano do tubo da corola.

32. Tabernaemontana flavicans Willd. ex Roem. \& Schult., Syst. Veg. 4: 7971819 . Fig. 7p-v

Arbusto 0,80-1,5 m alt.; ramos cilíndricos. Folha com pecíolo 1-8 cm compr., lâmina 4,5-13 $\times 1,2-4,5 \mathrm{~cm}$, cartácea a subcartácea, elíptica a estreito-elíptica, ápice cuspidado a acuminado, base cuneada a atenuada, faces adaxial e abaxial glabras, nervuras secundárias em 9-10 pares. Inflorescência dicasial, axilar, 3-5 flora; pedúnculo 0,5-1 cm compr.; brácteas 1,6-2 mm compr., triangulares, glabras. Pedicelo 0,3-1 cm compr. Cálice com lacínias 2-4 mm compr., iguais, ovais, glabras. Corola branca; tubo inferior $0,25-0,5 \times$ 2-3 cm, cilíndrico, tubo superior 0,6-1 × 0,3-0,7 $\mathrm{cm}$, cilíndrico, fauce amarela; lobos $2,5-3 \times$ 1,3-2,4 cm, ovados a obovados, patentes. Estames inseridos no terço superior do tubo; anteras 5-6 mm compr., dorso glabro. Gineceu com ovário 2,5-4 $\mathrm{mm}$ compr., glabro; disco nectarífero levemente 5-lobado, com um terço do comprimento do ovário; estilete 1,9-2,1 mm compr.; cabeça do estilete $1-1,8 \mathrm{~mm}$ compr., similar a um carretel, anel basal inconspícuo. Folículos 2,2-2,4 × 1,5-1,8 $\mathrm{cm}$, obliquamente elipsoides. Sementes 5-7 $\times$ 3,5-4 mm, elipsoides, levemente estriadas; arilo alaranjado a avermelhado.

Material selecionado: Muaná, Rio Anabijú, 2.XI.2011, fl. e fr., S.S. Viana et al. 37 (MG); Salvaterra, Chiquita, 25.XI.1988, fl, A.S.L. da Silva 2158 (MG); Vila Caldeirão, 24.VII.2011, fl., S.S. Viana 8 (MG).

Espécie com ampla distribuição geográfica, com registro para as regiões Norte, Nordeste, Centro-Oeste e Sudeste (BFG 2015). Segundo Leeuwenberg (1994), floresce de setembro a dezembro. $\mathrm{Na}$ área de estudo foi coletada com flores em novembro e julho e com frutos em novembro, em capoeira. Tabernaemontana flavicans distingue-se das outras espécies coletadas por apresentar ramos cilíndricos, folhas cartáceas a subcartáceas, cálice com lacínias glabras e margem não ciliada, disco nectarífero levemente 5-lobado, cabeça do estilete com projeções inconspícuas e semente com arilo alaranjado.

33. Tabernaemontana siphilitica (L.f.) Leeuwenb., J. Ethnopharmacol. 10: 17. 1984 Fig. 7w-y

Arbusto, 1-3 m alt,; ramos angulosos. Folhas com pecíolo 0,1-1 cm compr.; lâmina 10-18,5 $\times 3,2-6 \mathrm{~cm}$, subcoriácea a coriácea, elíptica a estreito elíptica, ápice agudo a cuspidado, base cuneada a aguda, face adaxial e abaxial glabras, com pontuações irregulares, nervuras secundárias em 13-15 pares. Inflorescência corimbiforme, axilar, 10-18 flora; pedúnculo 0,8-3 cm compr.; brácteas 1-2 mm compr., triangulares, glabras a pubescentes. Pedicelo 2-9 mm compr. Cálice com lacínias 2-3 mm compr., desiguais, ovais, pubescentes. Corola alva, tubo inferior $0,5-1,3$ 
$\times 0,2-0,4 \mathrm{~cm}$, cilíndrico com aspecto retorcido, tubo superior $0,6-1 \times 0,3-0,7 \mathrm{~cm}$, cilíndrico com aspecto retorcido, fauce alva; lobos 1,3-1,9 × 0,8$1 \mathrm{~cm}$, estreitamente obovados a elípticos, patentes. Estames inseridos no terço mediano do tubo; anteras 5-7 mm compr., dorso glabro. Gineceu com ovário 1,7-2 mm compr., glabro; disco nectarífero profundamente 5-lobado, concrescido ao ovário com um terço do comprimento deste; estilete 8-9 mm compr., retorcido, glabro; cabeça do estilete 1-1,5 mm compr., similar a um carretel, com anel basal membranoso. Frutos e sementes não observados.

Material selecionado: Afuá, Rio Marajozinho, 2.X.1992, fl., M.R. Santos 1875 (MG); Muaná, entre Rio Anajás e Rio Atuá, 18.I.1998, S.V. da Costa et al. 226 (MG); Porto Caiçara, 16.I.2005, fl., A.S.L. da Silva et al. 4191 (MG).

Espécie com registro de coleta nas regiões Norte, Nordeste e Centro-Oeste (BFG 2015). Floresce de julho a novembro (Leeuwenberg 1994), mas na área de coleta foi encontrada com flores em outubro e janeiro.

\section{Agradecimentos}

Ao CNPq, a concessão da bolsa de Mestrado ao primeiro autor. Ao Museu Paraense Emilio Goeldi (Coordenação de Botânica), a infraestrutura disponibilizada. À PROPED (UFRA), o auxílio financeiro para realização das coletas de campo e visita aos herbários. Aos curadores dos herbários, IAN, INPA, MG, R, RB, SP, SPF e UEC, o acesso ao acervo; e ao IAN e MG, o empréstimo de material. Ao ilustrador botânico Carlos Alvarez, a finalização das pranchas.

\section{Referências}

Amaral, D.; Vieira, I.C.G.; Salomão, R.P.; Almeida, S.S.; Silva, J.B.F.; Neto, S.V.C.; Santos, J.U.M.; Carreira, L.M.M. \& Bastos, M.N.C. 2007. Campos e florestas das bacias dos Rios Atuá e Anajás, Ilha do Marajó, Pará. Museu Paraense Emílio Goeldi, Belém. 110p.

BFG. 2015. Growing knowledge: an overview of seed plant diversity in Brazil. Rodriguésia 66: 1085-1113.

Bragatto,V.M. \& Kinoshita, G.L.S. 1994. As Apocynaceae da região de Poços de Caldas. Acta Botanica Brasilica 7: 107-127.

Brasil. Governo Federal. 2007. Grupo Executivo Interministerial. Plano de desenvolvimento territorial sustentável para o Arquipélago do Marajó: resumo executivo da versão preliminar para discussão nas consultas públicas / Governo Federal, Grupo Executivo Interministerial. Editora do Ministério da Saúde, Brasília. 24p.
Cruz, M.E.M. 1987. Marajó: essa imensidão de ilha. M.E.M. Cruz, São Paulo. 111p.

Endress, M.E. \& Bruyns, P.V. 2000. A revised classification of the Apocynaceae s.l. Botanical Review 66: 1-56.

Endress, M.E.; Liede-Schumann, S. \& Meve, U. 2014. An updated classification for Apocynaceae. Phytotaxa 159: 175-194.

Farinaccio, M.A. 2007. Sistemática molecular de Oxypetalum R. Br. (Apocynaceae, Asclepiadoideae). Tese de Doutorado. Universidade de São Paulo, São Paulo. 239p.

Farinaccio, M.A. \& Mello-Silva, R. 2004. Asclepiadoideae (Apocynaceae) do Parque Nacional da Serra da Canastra, Minas Gerais, Brasil. Boletim de Botânica da Universidade de São Paulo 22: 53-92.

Fontella-Pereira, J. (coord.). 2005. Asclepiadaceae. In: Wanderley, M.G.L.; Shepherd, G.J.; Melhem, T.S. \& Giulietti, A.M. (eds.). Flora fanerogâmica do estado de São Paulo. Instituto de Botânica, São Paulo. Vol. 4, pp. 93-156.

Goes, M.B. \& Pereira, J.F. 2009. Asclepiadoideae (Apocynaceae) no município de Santa Teresa, Espírito Santo, Brasil. Rodriguésia 60: 509-529.

Gonçalves, E.G. \& Lorenzi, H. 2011. Morfologia Vegetal: organografia e dicionário ilustrado de morfologia das plantas vasculares. $2^{\text {a }}$ ed. Instituto Plantarum de Estudos da Flora, São Paulo. 512p.

Harris, J.G. \& Harris M.W. 2001. Plant identificacion terminology: an illustred glossary. $2^{\mathrm{a}}$ ed. Spring Lake Publishing, Spring Lake. 206p.

Judd, W.S.; Campbell, C.S.; Kellogg, E.A.; Stevens, P.F. \& Donoghue, M.J. 2009. Sistemática vegetal: um enfoque filogenético. $3^{\mathrm{a}} \mathrm{ed}$. Artmed, Porto Alegre. $632 p$.

Kinoshita, L.S. (coord.). 2005. In: Wanderley, M.G.L.; Shepherd, G.J.; Melhem, T.S. \& Giulietti, A.M. (eds.). Flora fanerogâmica do estado de São Paulo. Instituto de Botânica, São Paulo. Vol. 4, pp. 35-92.

Kinoshita, L.S. \& Simões, A.O. 2005. Flora da Serra do Cipó, Minas Gerais: Apocynaceae s. str. (Rauvolfioideae e Apocynoideae). Boletim Botânico da Universidade de São Paulo 23: 235-256.

Koch, I. \& Kinoshita, L.S. 1999. As Apocynaceae s. str. da região de Bauru, São Paulo, Brasil. Acta Botanica Brasilica 13: 61-86.

Lawrence, G.H.M.; Buchheim, A.F.G.; Daniels, G.S. \& Dolezal, H. 1968. Botanicum-PeriodicumHuntianum. Hunt Botanical Library, Pittisburgh. $1063 p$.

Leeuwenberg, A.J.M. 1994. A revision of Tabernaemontana: the new world species and Stemmadenia. Vol. 2. Royal Botanic Gardens, Kew. Pp. 213-450.

Matozinhos, C.N. \& Konno, T.U.P. 2011. Diversidade taxonômica de Apocynaceae na Serra Negra, MG, Brasil. Hoehnea 38: 569-596. 
Monachiho, J. 1945. A Revision of Hancornia (Apocynaceae). Lilloa 11: 19-48.

Monguilhott, L. \& Mello-Silva, R. 2008. Apocynaceae do Parque Estadual de Ibitipoca, Minas Gerais, Brasil. Boletim de Botânica, USP 26: 93-130.

Montag, L.F.A.; Albuquerque, A.A.; Freitas, T.M.S. \& Barthem, R.B. 2009. Ictiofauna de campos alagados da Ilha do Marajó, estado do Pará, Brasil. Biota Neotropica 9: 1-13.

Morales, J.F. 1999. A synopsis of the genus Odontadenia: series of revisions of Apocynaceae XLV. Bulletin du Jardin Botanique National de Belgique 67: 381-477.

Morales, J.F. 2005. Studies in the neotropical Apocynaceae XIX: the family Apocynaceae (Rauvolfioideae, Apocynoideae) in Costa Rica. Darwiniana 43: 90-191.

Morales, J.F. 2007. Estudios en las Apocynaceae Neotropicales XXXI: el complejo de Mandevilla hirsuta y cuatro nuevas especies. Journal of the Botanical Research Institute of Texas 1: 859-869.

Morales, J.F. 2009a. Estudios en las Apocynaceae neotropicales XXXIX: revisión de las Apocynoideae y Rauvolfioideae de Honduras. Anales del Jardín Botánico de Madrid 66: 217-262.

Morales, J.F. 2009b. Apocynaceae Neotropicales XXXVII: Monografía del Género Rhabdadenia (Apocynoideae: Echiteae). Journal of the Botanical Research Institute of Texas 3: 541-564.

Morokawa, R.; Simões, A.O. \& Kinoshita, L.S. 2013. Apocynaceae s. str. do Parque Nacional da Serra da Canastra, Minas Gerais, Brasil. Rodriguésia 64: 179-199.

Pires, J.M. 1973. Tipos de vegetação da Amazônia. Publicação avulsa do Museu Paraense Emílio Goeldi 20: 179-202.

Radford, A.E.; Dickison, W.C.; Massey, J.R. \& Bell, C.R. 1974. Vascular plant systematics. Harper \& Row, New York. 891p.

Rangel, E.S. \& Nascimento, M.T. 2011. Ocorrência de Calotropis procera (Ait.) R. Br. (Apocynaceae) como espécie invasora de restinga. Acta Botanica Brasilica 25: 657-663.

Rapini, A. 2010. Revisitando as Asclepiadoideae (Apocynaceae) da Cadeia do Espinhaço. Boletim de Botânica da Universidade de São Paulo 28: 97-123.

Rapini, A.; Mello-Silva, R. \& Kawasaki, M.L. 2001. Asclepiadoideae (Apocynaceae) da Cadeia do Espinhaço de Minas Gerais, Brasil. Boletim de Botânica da Universidade de São Paulo 19: 55-169.

Rapini, A.; Chase, M.W.; \& Konno, T.U.P. 2006. Phylogenetics of South American Asclepiadoideae (Apocynaceae). Taxon 55: 119-124.

Sakane, M. \& Sheperd, G.J. 1987. Uma revisao do gênero Allamanda L. (Apocynaceae). Revista Brasileira de Botânica 9: 125-149.

Simões, A.O. \& Kinoshita, L.S. 2002. The Apocynaceae s. str. of the Carrancas Region, Minas Gerais, Brasil. Darwiniana 40: 127-169.
Simões, A.O.; Endress, M.E.; Van Der Niet, T.; Kinoshita, L.S. \& Conti, E. 2006. Is Mandevilla (Apocynaceae, Mesechiteae) monophyletic? Evidence from five plastid DNA loci and morphology. Annals of the Missouri Botanical Garden 93: 565-591.

Simões, A.O.; Endress, M.E. \& Conti, E. 2010. Systematics and character evolution of Tabernaemontaneae (Apocynaceae, Rauvolfioideae) based on molecular and morphological evidence. Taxon 59: 772-790.

Souza, V.C. \& Lorenzi, H. 2012. Botânica Sistemática: guia ilustrado para identificação de famílias de fanerógamas nativas e exóticas no Brasil, baseado no APG III. $3^{\text {a }}$ ed. Instituto Plantarum, Nova Odessa. $768 \mathrm{p}$.

Spina, A.P. 2004. Estudos taxonômicos, micromorfológico e filogenético do gênero Himatanthus Willd. ex Schult. (Apocynaceae: Rauvolóideae Plumerieae). Tese de Doutorado. Universidade Estadual de Campinas, São Paulo. 197p.

The Plant List. 2013. Version 1.1. Disponível em $<$ http:// www.theplantlist.org/>. Acesso em 1 janeiro 2013.

Thiers, B. [continuamente atualizado]. Index Herbariorum: a global directory of public herbaria and associated staff. New York Botanical Garden's Virtual Herbarium. Disponível em $<$ http://sweetgum. nybg.org/ih/> . Acesso em 20 dezembro 2013.

Vicentini, A. \& Olieira, A.A. 1999. Apocynaceae. In: Ribeiro, J.E.L.S.; Hopkins, M.J.G.; Vicentini, A.; Sothers, C.A.; Costa, M.A.S.; Brito, J.M.; Souza, M.A.D.; Martins, L.H.; Lohmann, L.G.; Assunção, P.A.; Pereira, E.C.; Silva, C.F.; Mesquita, M.R. \& Procópio, L.C. 1999. Flora da Reserva Ducke. Guia de identificação das plantas vasculares de uma floresta de terra firme na Amazônia Central. INPA-DFID, Manaus. Pp. 568-581.

Vieira Neto, R.D. 1994. Cultura da mangabeira. Embrapa-CPATC, Aracaju. 16p.

Villachica, L.H.; Carvalho, J.E.U.; Müller, C.H.; Diaz S.C. \& Almanza, M. 1996. Frutales y hortalizas promisorios de la amazonia. Tratado de Cooperacion Amazonica, Lima. 344p.

Watanabe, M.T.C.; Roque, N. \& Rapini, A. 2009. Apocynaceae sensu strictum no Parque Municipal de Mucugê, Bahia, Brasil, incluindo a publicação válida de dois nomes em Mandevilla Lindl. Iheringia, Série Botânica 64: 63-75.

Woodson Jr., R.E. 1935. Studies in the Apocynaceae IV. The american genera of Echitoideae. Annal of the Missouri Botanical Garden 22: 153-340.

Zarucchi, J.L. 1987 [1988]. A Revision of the Tribe Ambelanieae (Apocynaceae-Plumerioideae). In: Leeuwenberg, A.J.M. (ed.). Series of revisions of Apocynaceae, Part XXIV. Vol. 87. Agricultural University, Wageningen. Pp. 1-106.

Zarucchi, J.L. 1991. A new species of Parahancornia Ducke (Apocynaceae: Plumerioideae: Carisseae) with comments on the genus. Novon 1: 37-44. 


\section{Lista de coletores}

Almeida 281 (19); 355 (19). Bastos 83 (22); 2420 (25). Bruce 420 (22). Beck 208 (21). Bento 181 (26); 245 (26); 1977 (26). Black 48 (18); 50 (18); 3440 (24); 3544 (22); 3562 (29); 9928 (31); 14297 (31); 14314 (5). Bouças 140 (22); 174 (7). Bruce 420 (22). Carreira 1809 (30); 1899 (10); 1931 (20); 1947 (14); 1957 (24); 2462 (12). Cavalcante 3339 (19). Costa 197 (7); 226 (33); 509 (11); 510 (18); 511 (5); 512 (14); 523 (11); 528 (11); 529 (10); $531(20) ; 532$ (22); 533 (20); 535 (31); 536 (10); 537 (11). Cordeiro 1760 (20); 4814 (29). Daens 7047 (29). Dantas 1042 (11); 1082 (11); 1124 (31). Ducke 1237 (29); 1993 (29); 3553 (19); 7330 (19); 15519 (30); 15521 (27). Elias 207 (30). Egler 1523 (5). Félix-da-Silva 98 (7). Fróes 20751 (21). Huber s.n. (18). Jangoux 1205 (6). Lima 69(11). Lobato 4082 (7). Lisboa 3096 (16); 6724 (33). Maciel 771 (15); 1353 (28); 1778 (20); 1782 (13); 1885 (19); 1933 (28). Menezes-Neto 2733 (30). Neves 297 (31). Oliveira 402 (22); 2030 (11); 2081 (19); 2109 (31); 2599 (27); 3177(12); 4921 (22); 5044 (14); 5080 (14); 5109 (3); 5112 (31); 5171 (24); 5297 (12); 5971 (26); 6575 (13). Pinheiro 15 (30). Pires 699 (19); 1226 (24); 1427 (14); 1471 (30); 1481 (7); 1511 (25); 6738 (25); 10108 (25); 10225 (25); 10385 (25); 10559 (25); 10659 (25); 10756 (25); 10762 (25); 10803 (15); 11923 (25); 12046 (25). Prance 26336 (4); 30285 (16). Ramos 2 (30). Rocha 1058 (2); 1292 (24); 1294 (2). Ribeiro 169 (21); 193 (24). Rosa 908 (24); 927 (22); 1757 (21); 1767 (25); 2447 (1); 5466 (18); 5526 (29); 5528 (18). Rosário 118 (2); 125 (24). Santos 307 (6); 491 (19); 498 (29); 1875 (33); 1976 (9). Salomão 1264 (33). Silva 366 (14); 507 (27); 2391 (29); 4956 (5); 4974 (22). da Silva 2037 (11); 2060 (31); 2070 (23); 2158 (32); 2430 (6); 3121 (7); 3653 (6), 4178 (10); 4191 (33); 4218 (12); 4248 (8), 4269 (8). Sobel 4583 (26); 4661 (8); 4816 (6); 4857 (16); 4905 (12). Strudwick 4131 (19). van den Berg 68 (14). Viana 1 (11); 3 (23); 4 (15); 5 (22); 6 (20); 7 (10); 8 (32); 9 (18); 16 (15); 17 (30); 18 (20); 19 (13); 24 (16); 26 (18); 27 (1); 30 (32); 33 (8); 34 (12); 35 (23); 36 (12); 37 (32); 33 (8); 38 (29); 39 (32); 40 (13); 41 (13); 42 (8); 43 (3); 44 (25); 46 (10); 47 (16); 49 (32); 52 (20); 53 (27); 54 (17); 55 (30); 56 (10); 57 (9); 59 (23); 62 (3); 64 (20); 65 (22); 66 (24); 70 (18); 71 (5); 72 (20); 73 (10); 79 (4); 80 (24); 87 (21); 88 (29); 89 (29); 90 (21); 91 (24). 